\title{
True Painting and the Challenge of Hypocrisy ${ }^{1}$
}

\author{
Felipe Pereda
}

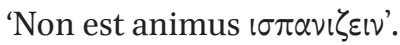

ERASMUS of Rotterdam (23 August 1517)

'Le vrai, toujours le vrai, c'est ta seule devise'. THÉOPHILE GAUTIER

Arguably the most influential date for the reception of Spanish painting is 1838 , the year the famous Galerie Espagnole or Spanish Gallery opened at the Louvre. There, more than 400 paintings of the Spanish Baroque were displayed, the result of careful collecting in the previous years by Louis-Philippe as part of an institutional campaign that cost the French government 1.3 million francs. ${ }^{2}$ The exhibition would last only ten years, but the impact it had in the European art world for both painters and critics alike can still be felt today.

1 The research in preparation for this study has received funding from the European Research Council under the European Union's Seventh Framework Programme (FP7/2007-2013) ERC Grant Agreement number 323316, CORPI project 'Conversion, Overlapping Religiosities, Polemics, Interaction. Early Modern Iberia and Beyond'. Previous versions of this text have been presented at several conferences (Jerusalem: 'Hypocrisy and Dissimulation in Judaism, Christianity and Islam', Center for Jewish Studies, The University of Chicago, Jerusalem, 2012; Northwestern University, 2013; the annual meeting of the Sixteenth Century Society Conference, Puerto Rico, 2013; Johns Hopkins University, 2013; Harvard University, 2014). The paper has benefited from the questions and discussions following it. Rebecca Quinn Teresi edited the text improving my limited English. I am particularly thankful to Stefania Pastore for discussing this argument with me over the years. This article is dedicated to her.

2 Francisco Almela y Vives, 'El poeta Théophile Gautier ante el pintor José Ribera', Archivo de Arte Valenciano, 32 (1961): pp. 24-38. On the reception of Spanish painting in nineteenthcentury France, see Ilse Hempel Lipschutz, Spanish Painting and the French Romantics (Cambridge: Harvard University Press, 1972); Alisa Luxenberg, The Galerie Espagnole and the

(C) FELIPE PEREDA, 2016 | DOI 10.1163/9789004324329_015

This is an open access chapter distributed under the terms of the CC-BY-NC-ND License. 
It was not only the moment in which painters of the generation of Édouard Manet were confronted for the first time with the works of Velázquez, Murillo or Zurbarán, with very well known artistic consequences, but was also the time when the existence of an École Espagnole was first seriously considered, lying somewhere on the margins of the best-known established artistic traditions, mostly those of Italy and Flanders.

'One leaves the Spanish gallery' - wrote one critic - 'dazzled by the brilliance of the colours, gripped by the energy of execution and the power of the truth of this original painting'. 'Truthfulness' was to become one of the keywords that critics would begin insistently using from the 1830s, the other one, 'devotion'. Most of the paintings painstakingly collected by Louis-Philippe's agent in Spain, Baron Taylor, were religious paintings, unambiguous in their intensity, and crude in their style. Art critics labeled Murillo as the artist of 'tender and amorous devotion', Zurbarán 'cadaverous and monastic', Ribera's martyrdoms, 'bloody and savage'. All painters, however, coincided in bringing to the heart of Paris the extreme piety and crude superstition that three centuries of the Black Legend had prepared people to expect coming from South of the Pyrenees. The romantic fascination with Spanish paintings and its pervasive rhetoric continues to poison the art historical well. While recent literature and a few important exhibitions have revisited Spanish baroque painting not in isolation from but in creative dialogue with the artistic currents of its time, they have done nothing but reinforce the idea that Spanish art was the truthful expression of Spaniards' deep, almost primitive religiosity. Sincere belief became a condition of Spanish painting, one that at the same time distinguished this tradition and rendered it exotic.

Interestingly, a more complex understanding can be read in between the lines of the most perceptive comments of the French critics of the French Galerie Espagnole. In one of the earliest reactions recorded, Théophile Gautier praised Ribera's commitment to pictorial truth (le vrai, toujours le vrai) with verses that paradoxically coupled his obsessive representation of martyrdoms with the suggestion that, far from being the expression of orthodox faith, Ribera's work was in fact the traumatic result of the artist's birth in a land infected with converted Jews and Muslims:

Reckless peasant, sketchy beggar

Moor that baptism could hardly make a Christian [emphasis mine]

While another might seek the beautiful, you seek out the shocking

... the truth, always the truth, it's your only currency.

Museo Nacional 1835-1853: Saving Spanish Art, or the Politics of Patrimony (Aldershot: Ashgate, 2008). 
By the time it had reached Gautier's verses in 1838 , the 'trope' of Spaniards' insincere religiosity was little more than a poetic fossil, used as in this poem less to respond to the intrinsic violence of the painting than to stimulate if not produce the reader's estrangement. But this had not always been the case, rather quite the opposite. As I would like to explore in this article, there is a long history behind this trope, one that goes back to a crucial moment in the history of Spanish painting, a time when the tension between Spaniards' religious images as the signs or expression of their interior beliefs had become problematic. And what is important for an art historian, a time when the need to fix or bridge in painting what seemed broken or incomplete in social life conversion, in the terms of the poem - became a major force of artistic creativity ${ }^{3}$. In order to uncover this track we will not only need to recuperate the early history of the cultural, even 'racial', prejudice expressed in Gautier's poem, but also like him, to problematize the relation of religious painting to people's beliefs: not to question them, but not to take them for granted either. It is in the paintings themselves, I will argue, and not anywhere 'behind them', that I believe these anxieties can be read. Needless to say, my goal is not to reinstate Gautier's romantic approach but, on the contrary, to follow his poetic intuition, and consider Spanish early-modern religiosity not as the solution or the response to the extreme confessional nature of its artistic culture, but instead, as the problematic condition from which to rethink its obsession with truth.

In order to explore this problem I will look into some very precise as well as thoroughly documented works of the mid-sixteenth century at a key moment in the process of the creation of Spanish devotional painting. First, however, I need to historically problematize our current use of the word 'devotional'. Illustrative will be the case of Esteban Jamete, a sculptor tried for heterodoxy. Arrested in the year 1557, Jamete represents a extraordinarily well-documented example of Protestant 'Nicodemism' in sixteenth-century Spain, a term coined by Calvin to refer to those people who followed common religious practice by hiding their true heterodox convictions. ${ }^{4}$ According to the document recording his Inquisitorial trial, while he attended to his religious duties

3 For the broader cultural implications of early modern discourses of ethnicity, see for example, James Taylor, 'Why do you tear me from Myself?': Torture, Truth and the Arts of the CounterReformation,' in The Rhetoric of Sincerity, (ed.) Mieke Bal and Hent de Vries (Stanford: Stanford University Press, 2009), pp. 19-43.

4 'Nicodemism' refered to crypto-Protestants living in Catholic land. The term however began to circulate after 1544. See Carlo Ginzburg, Il nicodemismo. Simulazione e dissimulazione religiosa nell'Europa del '50o (Turin: Einaudi, 1970), and the critique of Carlos Eire, 'Calvin and Nicodemism: A Reappraisal', Sixteenth Century Journal, 10 (1979): pp. 45-69. See also, Pérez 
as would any other citizen of Cuenca, the Castilian city where he established his workshop in 1545 , his private life was troublingly at odds with his public behavior. Several of the colleagues or apprentices who had collaborated with him vividly recalled the lyrics of a song he used to sing while at work: 'El papa de Roma que se faze Dios engaña a los hombres en cada un lugar, matad vuestras candelas, ypocritas, ypocritas, dexad los ydolos e adoremos a Dios' (The Pope in Rome, who behaves as if he were God, fools men wherever he goes, put out your candles, Hypocrites, Hypocrites, give up your idols, and let us adore God). ${ }^{5}$

What we know of the sculptor's life sheds some light on his strange behavior. Born in Orléans (France) at the beginning of the century, Esteban or Étienne Jamet had arrived in Castile in his twenties attracted by the wealth of its artistic market. Although he claimed that his religious convictions had been corrupted after his arrival in Castile, it is more convincing to think that Jamete himself had been an active agent in the dissemination of heretical ideas. The transcript of his trial suggests that his spiritual convictions had slowly matured from some kind of mild skepticism of Catholicism towards a mixture of anticlericalism and certain Calvinist beliefs. This transformation was partly a matter of personal choice, but it was influenced by exposure to the thoughts and ideas of his fellow artists, most of whom came from France, Flanders and other parts of Northern Europe. Perhaps Jamete thought that his status as a familiar of the Holy Office - the tight denunciation network that the Inquisition had woven by the recruitment of thousands of working-class members offered him a degree of protection; or maybe it was just his love of wine that

Zagorin, Ways of Lying: Dissimulation, Persecution and Conformity in Early Modern Europe (Cambridge: Harvard University Press, 1990), pp. 63-99.

5 Jesús Domínguez Bordona, Proceso inquisitorial contra elescultor Esteban Jamete. Transcripción, extractosy notas preliminares (Madrid:JAE, 1933), p. 23. On Jamete's heretical ideas, see Werner Thomas, Los protestantes y la Inquisición en España en tiempos de Reforma y Contrarreforma (Leuven: University of Leuven Press, 2001), pp. 635-37; María Luz Rokiski Lázaro, 'Proceso de Alexandre Francés y noticias de artistas que trabajaron en Cuenca', Archivo español de arte, 184 (1973): pp. 440-48; Jean-Louis Flecniakoska, 'La propagation des idées protestantes par les français en Espagne et l'Inquisition de Cuenca, 1554-78', Bulletin de la societé de l'histoire du Protestantisme français, 120 (1974): pp. 532-54. For Jamete's biography see André Turcat, Étienne Jamet alias Esteban Jamete. Sculpteur français de la Renaissance en Espagne, condammé par l'Inquisition (Paris: Picard, 1994); Richard L. Kagan and Abigail Dyer, 'Protestant Threat? Esteban Jamete', in Inquisitorial Inquiries: Brief Lives of Secret Jews and Other Heretics, (ed.) R. Kagan and A. Deyer (Baltimore:Johns Hopkins University Press, 2011), pp. 36-63; and soon, Fernando Marías, 'Censurando imágenes públicas. La Inquisición y una estampa de Esteban Jamete' (forthcoming). 
loosened his tongue. Whatever the case, at the time of his arrest, Jamete had become outspokenly anticlerical, and sharply critical of the Papacy together with some of the fundamental doctrines of the Church. First, he forbade his wife from attending mass, he attended church only on a sporadic basis, and when he did, only for the reading of the Gospel and the consecration (for different reasons in each case). He also participated in debates involving such delicate subjects as the meaning of Trinity, and began to share some wild ideas with a widening circle of relatives and friends, including casting doubts on the existence of Purgatory and the reality of the sacraments. Finally, it seems that he denied public reverence of religious images to the point of radically questioning their presence in altarpieces. As he put it to one of his pupils, the Burgundian Isaac de Juni:

it was not right to put [images of] Saints in the altarpieces, and it would be better to decorate them with other carvings and fantasies, but not images of Saints and their stories, as people were so absorbed in praying to those images that often they did not even pay attention to the Holy Sacrament. ${ }^{6}$

Such an indiscreet remark was not out of the ordinary in sixteenth-century Spain except for the fact that Jamete, of course, was an artist, working mostly as a sculptor. Although during the three decades he spent in Spain Jamete usually avoided the manufacture of cult images, having specialized instead in producing decorative architectural elements, his work often forced him to work in the making of more iconic works. To offer only one example, in one altarpiece from the Cathedral of Cuenca, dated $155^{1-52}$, five years before his arrest by the Inquisition, Jamete collaborated with a local painter. Martín Vázquez made the figures of two fullsize saints against a gold ground - a tradition that would most probably be considered old-fashioned in many parts of Europe at this time, but was to survive in Castile well into the sixteenth century. Meanwhile Jamete provided the wooden structure, including not only decorative 'fantasies' - as he would later recommend to his pupil - but also an image of the Veronica, one of the favourite targets of Calvinist attacks on Roman idolatrous practices. As developed in Calvin's Treatise of Relics (1543),

6 'que no era bien poner santos en los retablos, que antes era mejor adornar los retablos de otras tallas o fantasias que no ymaginarias de Santos e sus ystorias porque la gente se embebeçia tanto en rezar a aquellas ymagines que muchas vezes no se acordaban del Santo Sacramento'. Domínguez, Proceso Inquisitorial, p. 10. 
the Veronica, together with the Holy Shroud, brought shame to the Christian cult as it had no Scriptural support but only that of superstitious traditions. ${ }^{7}$

That Esteban Jamete would have worked carving this Veronica, while at the same time whispering his favourite French song - 'Hypocrites, Hypocrites, give up your idols, and adore God' - should at least alert us to the serious problem with using the term 'devotional' in an unproblematized way. When it comes to artists, Nicodemism has attracted little in the way of scholarly attention, despite the fact that foreign-born artisans (this category including artists) were one of the social groups most closely policed by the Holy Office. After those working in the textile and printing industries 8 it was artists or artisans - sculptors, painters, clockmakers and silversmiths according to the statistics collected by Werner Thomas - that constituted the largest number of the accused in Inquisitorial jails between 1519 and 1648,43 percent of the jailed foreigners. ${ }^{9}$

Jamete's case is interesting for multiple reasons. The most obvious is that it questions the non-reflexive correspondence between devotional art and religious belief. Second, more interesting and challenging in the eyes of an art historian, is whether this separation between ritual practice, art making and belief that Jamete called 'hypocrisy' - a situation that he not only denounced but to which he contributed - can tell us something about the kind of strategic decisions that artists made in this period: in this precise case, for example, the conflation of image and relic in the Veronica, or the use of the old-fashioned gilt background for cult images in the retablo [see fig. 13.1]. Because, as Jamete's example shows, the tension between representation and belief always takes the point of view of an outsider (no one, apparently not even Jamete, thinks or thought of himself as a being a hypocrite), in the rest of this paper I will explore this tension's artistic consequences by taking just such an external perspective: that is the paintings Sebastiano del Piombo made for Spanish patrons, and their reception.

7 Jean Calvin's Traité des reliques first appeared in Geneva in 1543, to soon be translated into several languages (Latin, German, English, Flemish). On Calvin's attitude towards relics and images, see Carlos Eire, War Against the Idols: The Reformation of Worship from Erasmus to Calvin (Cambridge: Cambridge University Press, 1986), pp. 195-233.

8 Clive Griffin, Journeymen-Printers, Heresy and the Inquisition in Sixteenth-Century Spain (Oxford: Oxford University Press, 2005).

9 Thomas, Los protestantes y la Inquisición, p. 175ff. There is nothing original about such proportions. See for example the case of Venice, John Martin, Venice's Hidden Enemies: Italian Heretics in a Renaissance City (Baltimore: Johns Hopkins University Press, 2004), pp. 244-46. 


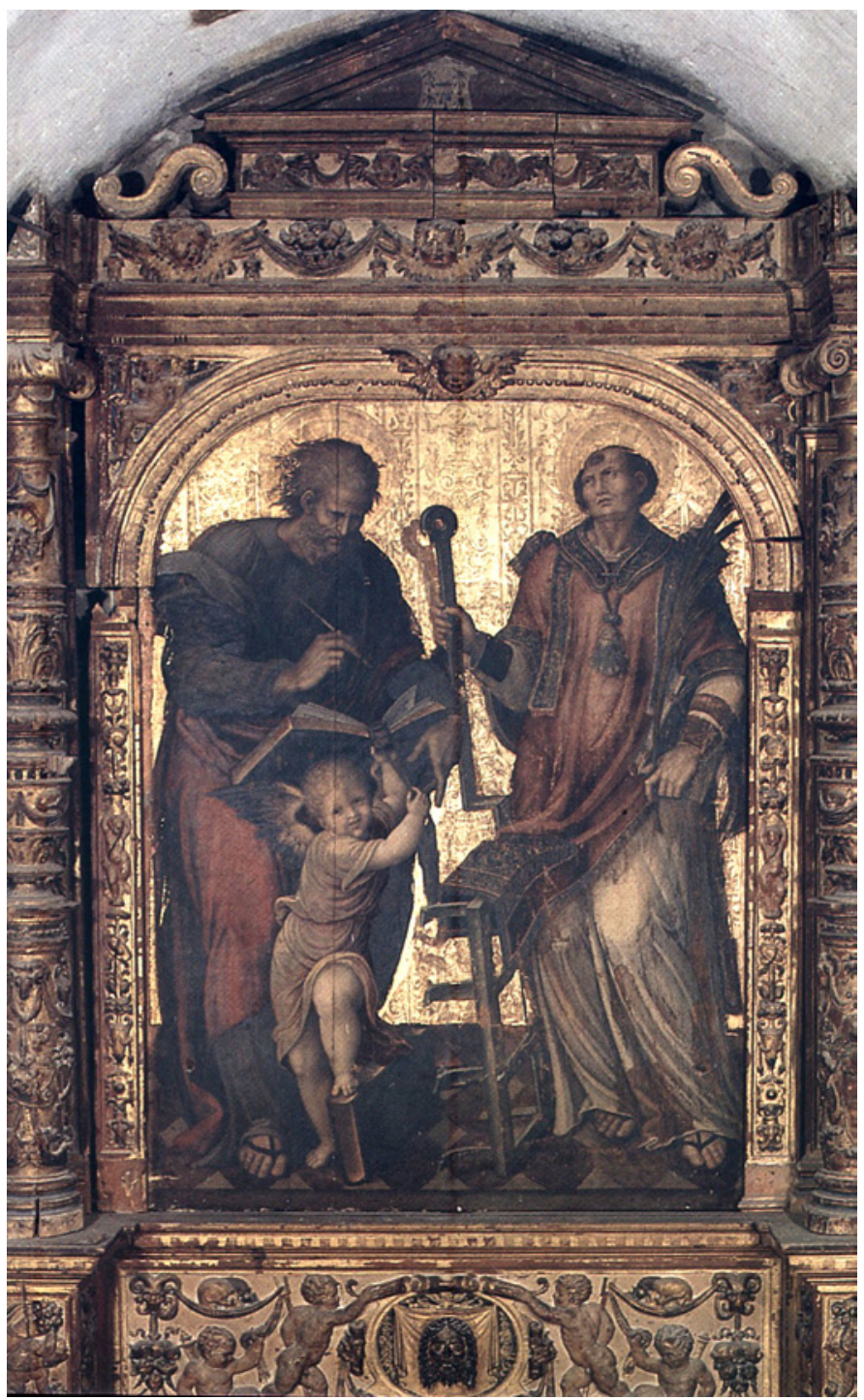

FIGURE 13.1 Martín Gómez el Viejo and Esteban Jamete, Altarpiece (1551-52). Cathedral of Cuenca (Archivo Catedralicio, Cuenca).

\section{The Cobos Pietà}

To provide a background to what is arguably one of the most influential paintings ever imported to the Iberian Peninsula, Esteban Jamete's biography can be of help. During the three decades he spent in Spain, Jamete enjoyed the 
protection of some very important patrons, both religious and secular authorities. Among them the most relevant was doubtlessly Francisco de los Cobos (Úbeda, ca. 1497-1547), counselor to the Emperor Carlos V and Grand Commander of the military Order of Santiago at the time of his 1530 journey to Italy on the occasion of his Imperial coronation. ${ }^{10}$ As Cobos managed to have Titian paint a portrait of his mistress, Cornelia, his Italian sojourn certainly shaped his interest in the new allantica architecture (called al romano in Spain). ${ }^{11}$ Jamete worked for the decoration of his palace in Valladolid in the 1530s, and was called again by Cobos in 1540 to work on the construction of his magnificent Renaissance funerary chapel in Úbeda (Jaén, Andalusia). Among many other sculptures, the French artist contributed some of the earliest representations of pagan gods of the Spanish Renaissance, carved in the interior part of the triumphal arch leading into the chapel, a task about which, we might assume, he felt much more comfortable ${ }^{12}$ [see fig. 13.2].

It was for this same chapel that Francisco de los Cobos commissioned the so-called 'Cobos Pietà' from Sebastiano del Piombo in Rome, today in the Prado Museum (Madrid), a painting that might be considered the paradigm of the 'devout mode' that guided Spanish commissions in Renaissance Rome. ${ }^{13}$ The painting is extraordinarily well documented thanks to a handful of very impor-

10 Hayward Keniston, Francisco de los Cobos: Secretary to the Emperor Charles V(Pittsburgh: University of Pittsburgh Press, 1960). On the chapel itself, see Caroline Horstmeier, 'Die Sacra Capella de El Salvador in Úbeda (Andalusien): eine Studie zur Memorialkunst und Sepulkralkultur der Neuzeit in Spanien' (PhD Diss., Freie Universität Berlin, 2011); for Jamete, pp. $5^{0-} 5^{2}$.

11 On Cobos' art patronage in Italy, particularly Titian's portrait of Cornelia see Diane H. Bodart, Tiziano e Federico II Gonzaga. Storia di un rapporto di committenza (Rome: Bulzoni, 1998), esp. pp. 80-81, and documents: 66, 71, 74, 75, 78, 82, 85 (pp. 217, 219, 220-222, 224 and 225). There are also extensive references to his role as commissioning mediator in Matteo Mancini, Tiziano e le Corti D'Asburgo: Nei Documenti degli Archivi Spagnoli (Venice: Istituto veneto di scienze, lettere ed arti, 1998), pp. 23-26; Francesco Caglioti, 'Il San Giovannino mediceo di Michelangelo da Firenze a Úbeda', Prospettiva, 145 (2012): pp. 2-81, considers (24-33) that the marble 'San Giovannino' destroyed in Úbeda in 1936 might have arrived to Cobos' hands during his stay in Florence in 1536.

André Turcat, Étienne Jamet alias Esteban Jamete. Sculpteur français de la Renaissance en Espagne, condammé par l'Inquisition (Paris: Picard, 1994).

Miguel Falomir, 'Sebastiano e il 'gusto spagnolo", in Sebastiano del Piombo 1485-1547 (Milan: F. Motta, 2008), pp. 66-71; Falomir, 'Dono italiano e 'gusto spagnolo' (1530-1610)', in L'arte del dono. Scambi artistici e diplomazia tra Italia e Spagna, 1550-165o, (ed.) Marieke von Bernstorff and Susanne Kubersky-Piredda (Rome: Silvana Editoriale, 2014), pp. 13-26; Piers Baker-Bates, 'Sebastiano del Piombo's Úbeda Pietà: Between Italy and Spain', Art, Site and Spectacle: Studies in Early Modern Visual Culture. Melbourne Art Journal, 9 (2007): pp. 34-43. Particularly interesting on 'devout' painting is the documentation collected in 


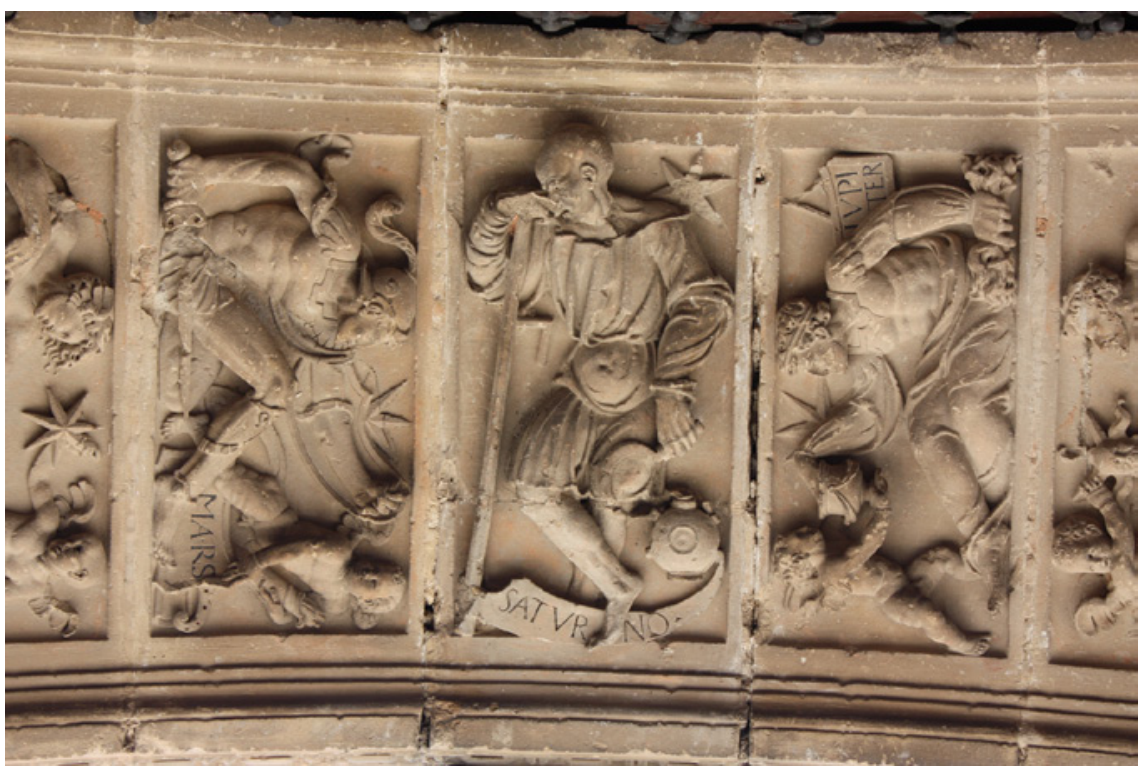

FIG URE 13.2 Esteban Jamete, Sacra capilla de El Salvador (Úbeda, Jaén), entry arch, interior. Fundación Casa Ducal de Medinaceli.

tant letters published by Michael Hirst that give a detailed account of the six-year-long process of negotiations beginning in 1532. ${ }^{14}$ It was not until 1539 that it finally made its way, through Genoa, and maybe Valladolid, to its final destination in Úbeda. ${ }^{15}$ Surprisingly, the letters by the Duke's Roman secretary express an ambivalent, at points even critical stance towards Sebastiano's 'Spanish' paintings. If on the one hand they refer to their pious nature, they also suggest that Spanish interest in painting's devotional mode was a sign of

Edward L. Goldberg, 'Circa 16oo: Spanish Values and Tuscan Painting', Renaissance Quarterly, 51 (1998): pp. 912-33.

14 Michael Hirst, 'Sebastiano's Pietà for the Comendador Mayor', The Burlington Magazine, 114 (1972): pp. 585-95. Documents had been previously, although fragmentarily, published in Giuseppe Campori, Sebastiano del Piombo e Ferrante Gonzaga (Vincenzi, 1864) and Pietro D'Achiardi, Sebastiano del Piombo (Rome, 1908). Cobos would have seen the painting before 31 March 1538: Clifford M. Brown, 'A Further Document for Sebastiano's Ubeda 'Pietà', The Burlington Magazine, 132 (1990): pp. 570-71.

15 And not through Sicily the year after, as Hirst thought. See Sylvie Deswarte-Rosa, 'Domenico Giuntalodi, peintre de D. Martinho de Portugal à Rome', Revue de l'art, 80 (1988): pp. 52-6o. 
simulation or moral deceit. ${ }^{16}$ As Miguel Falomir for example has noticed, the letters express a prejudice very widespread in Italy: a suspicion towards the faithfulness of Spanish religiosity that was grounded in Spain's long history of mass conversions. ${ }^{17}$ On the other hand, however, the emotional overtones of the paintings have been systematically read as an expression of Spanish 'interior' religiosity, without considering the strategic move of the artist to meet specific requirements.

In my opinion it is much more fruitful to read both the Italian moral criticism expressed in these letters and the Pietà's style not as different aspects of the painting's context but as part of one and the same discourse; in other words, consider Sebastiano's Spanish paintings as sophisticated exercises created to address and at the same time negotiate with the (hypocritical) Spanish 'taste'. In the last part of this article I will briefly look into the history of the painting's afterlife in Spain in the mid-sixteenth century. By exploring Sebastiano's Spanish reception, I hope to shed some light on the problematic nature of Spanish visual confessionalism. With this perspective in mind, let us return to the painting as it is first mentioned in the letters.

In Spagna piacciono le pitture di devozione con attitudine quiete, senza svolgimenti (In Spain, they like devotional paintings, with calm attitudes, without [excessive] gestures). The sentence does not refer to one of Sebastiano's paintings but to a 1599 commission made in Florence for the Marquesa del Valle. ${ }^{18}$ The claim, however, was equally true half a century before, and even more so further into the past as I will shortly demonstrate. Most probably painted for the altar of Francisco de los Cobos' magnificent funerary chapel, the solemn 'Cobos Pietà' is first mentioned in 1533 in a letter written by the Roman agent of the Gonzaga court. The letter's recipient, Ferrante Gonzaga, who was ultimately responsible for the commission, had first-hand information of Spanish 'taste', as his mother - none other than one of the most accomplished patrons of Renaissance Italy, Isabella d'Este - had him travel to the Iberian Peninsula and join the Emperor's court between 1523 and $1524 .{ }^{19}$ Back in Mantua, Ferrante

16 According to Sebastián de Covarrubias, 'hipocresía ... vale disimulación, fingimiento, apariencia exterior', Tesoro de la Lengua Castellana o Española [1610] (Madrid: Castalia, 1995), p. 638.

17 Falomir, 'Sebastiano e il "gusto spagnolo"'.

18 Goldberg, 'Circa 16oo'.

19 Considering his correspondence with his mother, Isabella d'Este, Spanish art, much less Spanish architecture, raised little interest or praise. His secretary, Pandolfo di Pico della Mirandola, only refers to the brutissimi edificii ala fogia de Spagna, and the only image mentioned is a 'San Giacomo' that Ferrante acquired in Santiago de Compostela to send it to his mother, assuming that it would please her, perché ha tocato tutte queste sante 


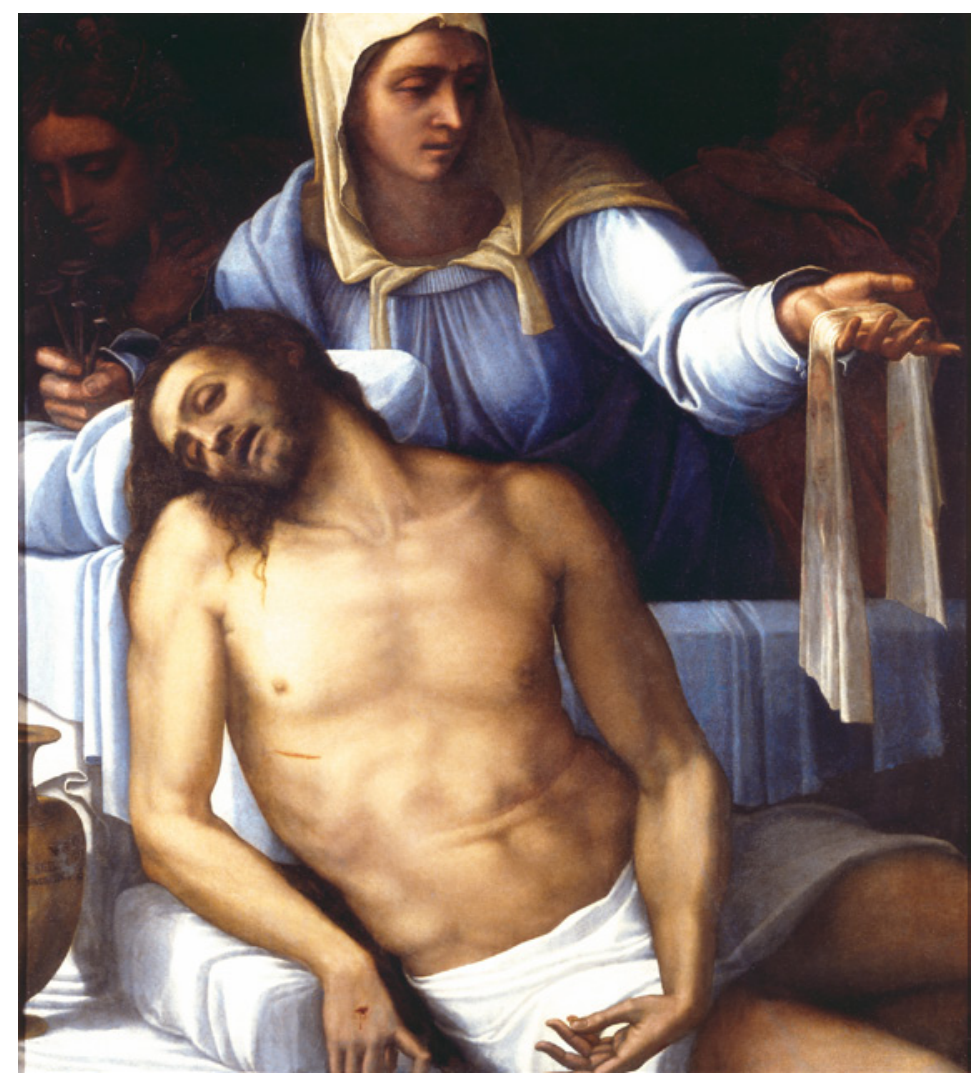

Figure 13.3 Sebastiano del Piombo, Cobos Pietà, $111 \times 124$ cm (ca. 1540). Fundación Casa Ducal de Medinaceli.

now struggled to find a painting that would please the powerful counselor of the Emperor to decorate the magnificent funerary chapel that he was beginning to build in his native town of Úbeda, in Andalusia.

In this first letter Ferrante's ambassador Nino Sernini explains how the painter had offered two different models to paint: first, a Virgin and Child, the other - which was the one finally chosen - a Pietà, 'our Lady with her Son in her arms, a guise di quella della febre', that is, in the form of Michelangelo's Pietà at the Vatican. To this Sernini added 'that the Spanish, to simulate being

reliquie ... Both in Raffaele Tamalio, Ferrante Gonzaga alla corte spagnola di Carlo V nel carteggio privato con Mantova (1523-1526). La formazione da 'cortegiano' di un generale dell'impero (Mantua: Arcari, 1991), p. 82, p. 240. 
good Christians (per parer buon Cristiani), usually love these sorts of pious things (cose pietose)'.

Sernini's characterization of Spanish taste was thoughtfully oriented to find the right and successful gift for the Emperor's counselor. In the previous years, Spanish patrons had become an important part of Sebastiano's market. Clerics who happened to live in Rome - as was the case of the Burgos canon Díez de Lerma - and several Spanish ambassadors, all of whom ended their lives buried in magnificent funerary chapels in their native country, commissioned works from Sebastiano. ${ }^{20}$ These Spanish commissions fostered a tendency towards a dramatic simplicity that is already perceived in Sebastiano's narrative paintings, but was only fully developed in his close-up depictions of passion scenes. Jerónimo Vich y Valterra, ambassador to Fernando the Catholic (1506-16), had him paint a very important triptych for his private chapel in Valencia, but also one Portacroce where the narrative is reduced at the expense of its iconicity. This process culminates in two more versions of the same subject painted for Spanish patrons, one of them yet to be identified [see fig. 13.3], the other for the ambassador's successor in Rome, the Count of Cifuentes, a gloomy version of Christ carrying the cross to which I will return shortly [see fig. 13.4].

At the same time, Sernini's identification of 'pious' painting with a Spanish urge to show off their status as good Christians, and his association of devotional painting with simulation, has a complex background. Before we further explore the context for this prejudice, however, let us look briefly into the evidence provided by the Cobos Pietà. ${ }^{21}$ Sebastiano worked from a drawing probably provided by Michelangelo in order to compose a painting that looks for a balance between late medieval devotional models and modern artifice. ${ }^{22}$ Christ's body is fully exposed to the viewer, with the Virgin Mary at his back having no physical contact with his sacramental body. Its dramatic effect is enhanced by the painting's support, black slate, a very exceptional medium

20 Fernando Benito Domenech, 'Sebastiano del Piombo y España', in Sebastiano del Piombo y España (Madrid: Museo del Prado, 1995), pp. 41-79.

21 Michael Hirst, Sebastiano del Piombo (Oxford: Oxford University Press, 1981), pp. 128-31.

22 Alexander Nagel, Michelangelo and the Reform of Art (Cambridge: Cambridge University Press, 2000), pp. 151-53. For Michelangelo's drawings in relation to the Cobos Pietà see also Erwin Panofsky, 'Die Pietà von Ubeda. Ein kleiner Beitrag zur Lösung der Sebastianofrage', in Festschrift für Julius Schlosser zum 6o. Geburtstage (Zürich Leipzig, Viena: Amalthea, 1927), pp. 150-61, who considers but leaves unanswered the question of whether the drawing was made with the Spanish commission in mind. 


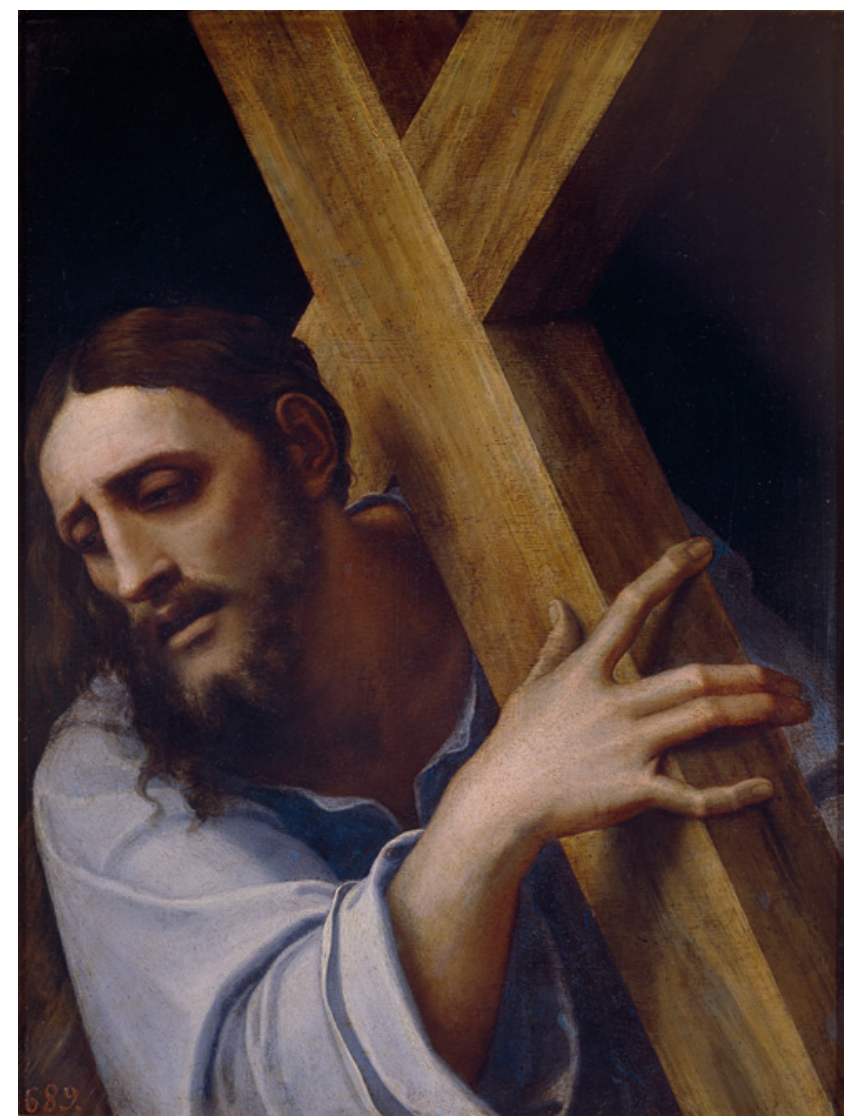

FIgURE 13.4 Sebastiano del Piombo, Christ carrying the Cross, $43 \times 32 \mathrm{~cm}$, oil on slate, $\left(153^{2-} 35\right)$. (C) Madrid, Museo Nacional del Prado.

with which, according to Pietro Bembo, ${ }^{23}$ Sebastiano had begun experimenting some years before in order to render his works 'eternal.' ${ }^{24}$

23 Pietro Bembo to Vittore Soranzo, Camariere Clement vis: 'i colori súbito che sono asciutti, si uniscono col marmo di maniera che quasi impetriscono, et ha fatto ogni prova et è durevole. Ne ha fatto una imagine di Christo et halla mostrato a N. Sig.' Cited by Hirst, Sebastiano del Piombo, p. 124.

24 Although I cannot follow up on this connection at this time, it would be worthwhile to remember not only that black slate was especially preferred by Sebastiano's Spanish patrons, but also that, when some years after, Titian received his first commission of a devotional passion-panel from Emperor Carlos V, slate was again the support requested by the patron. 


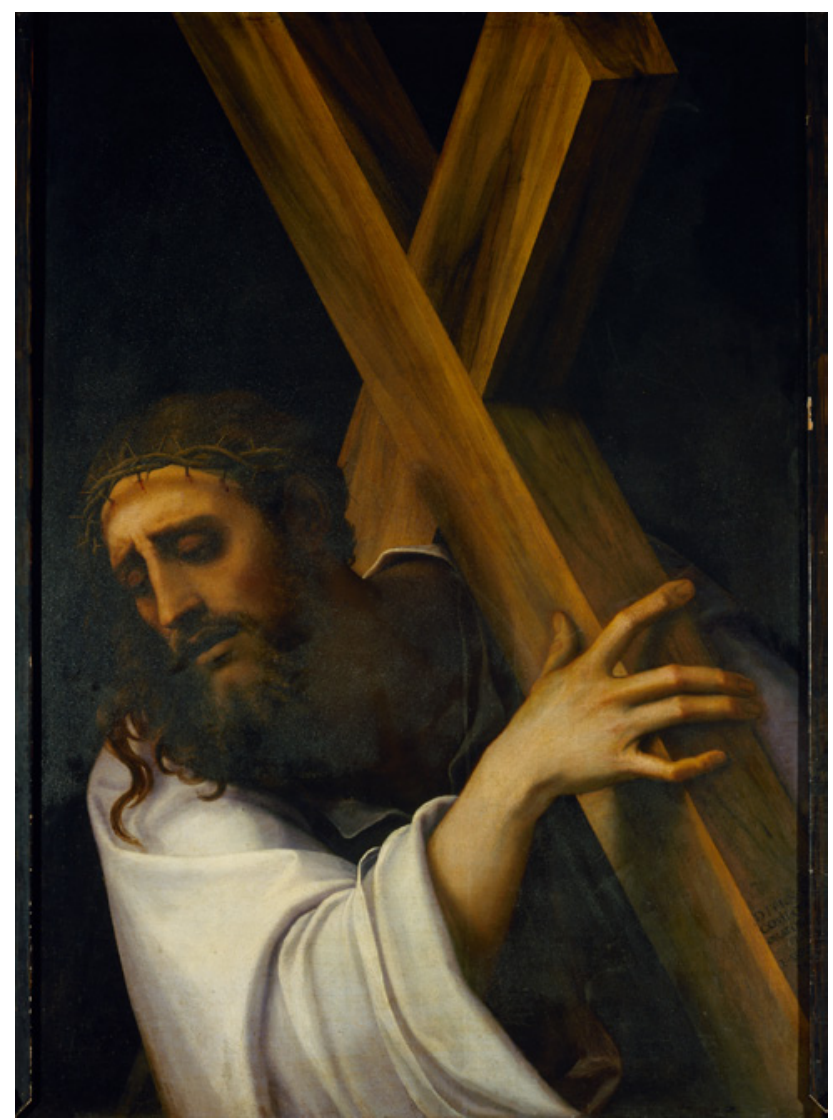

FIGURE 13.5 Sebastiano del Piombo, Christ carrying the Cross, $104.5 \times 74.5 \mathrm{~cm}$, oil on slate, $(1537)$. The State Hermitage Museum, St Petersburg.

Sebastiano's Pietà is also unique in its iconography: the Virgin hovers behind the sepulcher where her son's body lies dead. This is covered with a white cloth wrapped around the tomb's border. Two more characters, maybe apostles, seem to attend the scene from the shadows, one entering the sepulcher, the second leaving. ${ }^{25}$ The Virgin holds three nails in her right hand, and a second piece of cloth upon which Christ's face is printed, with her left. As far as I know there is no precedent for this iconography either in Italian or in Spanish painting. The figure has been identified as a non-narrative image, a sort of conflation

25 Only in-person viewing can fully perceive these two figures which, notwithstanding, must have been clearly perceptible in the sixteenth century, as none of the panel's copyists failed to interpret their meaning. 
of the Virgin with the Veronica but, as I will suggest later, a much more economic and historical explanation is in my understanding possible. ${ }^{26}$

If the support and its composition render the painting extremely severe, this contrasts with the emotional expression that we can read in it. There are few signs of grief: there is neither blood on Christ's breast nor any other sign of the passion in his body, nor tears flowing from Mary's eyes who, instead, stares stoically at the cloth hanging from her hand. What Ferrante Gonzaga's Roman agent meant when he said that the Spanish liked 'simulating' devotion can now be better understood, but also complicated, against the backdrop of this visual evidence. Sebastiano's mastery of devotional subjects was very well known across Italy, but his emotional tendency was also troubling. Alexander Nagel has noticed that the letter's concern is not an isolated document, but one among a larger number of testimonies expressing an increasing tension between the aesthetic and religious functions of devotional paintings in Italy. ${ }^{27}$ Without leaving the realm of the Gonzaga patronage, in 1524 Ferrante's brother Federico, the Marquis of Mantua, when asking for a painting by Sebastiano's hands, underlined that it should be 'of any kind so long as it is not about saints, but a picture that is lovely and beautiful to look at' (una qualche pictura vaghe et belle da vedere). More interesting though, when three years later (1527) Pietro Aretino mediated in a commission by the same artist and for the same patron, he wrote: 'I have written to Sebastiano, miraculous painter, that your will is that he makes a painting with whatever invention he likes, only, that there should be no hypocrisies (ipocrisie), nor stigmata, nor nails.28 That Sebastiano would paint exactly such a 'hypocritical' panel for Francisco de los Cobos, a painting that was to be considered an exercise in 'simulation', is enlightening, but must also be considered carefully. At this point, it might be necessary to clarify what exactly the term 'hypocrite' might have meant for these actors.

26 See most recently Elena Calvillo, 'Authoritative Copies and Divine Originals: Lucretian Metaphor, Painting on Stone, and the Problem of Originality in Michelangelo's Rome', Renaissance Quarterly, 66 (2013): pp. 453-508.

As cited in Alexander Nagel, 'Experiments in Art and Reform in Italy in the Early Sixteenth Century', in The Pontificate of Clement vII: History, Politics, Culture (Farnham: Ashgate, 2005), pp. 385-409; Nagel, The Controversy of Renaissance Art (Chicago: University of Chicago Press, 2011).

28 Nagel, 'Experiments in Art.' The letter is in Pietro Aretino, Lettere. Il primo e il secondo libro (Milano: Mondadori, 1960), p. 8; it is also in Bodart, Tiziano e Federico, doc. 20, p. 197. 


\section{On Hypocrisy}

Hypocrisy, according to Thomas Aquinas, is a lack of correspondence between the sign and its reference, between signum and signatum, between outward words, deeds or any sensible objects and what they pretend to signify. ${ }^{29}$ It is a corruption of language. This might help us interpret the 'hypocrisies' referred to by Aretino, the pious 'signs' to be read on the surface of the painting. In fact, while the wound occupies the center of the composition, it is discretely drawn on his breast as a thin line, almost illegible. Regarding the nails, reflectography shows that the composition went through very few changes during its process, but among which is one very significant for us now: the nails were originally much bigger, but he had them corrected to make them look smaller, a sign, it can be argued, of the painter's insecurity on this sensitive matter. Again, Christ's Classical, Apollo-like beauty is not deformed by the signs of the passion experienced by his body. Sebastiano struggled to meet the requirements of his patron, or what it was he thought his patron would have liked, while at the same carefully lessening what would have exposed him to moral criticism. Of what kind?

Aretino's censure of Sebastiano can be read as a general aesthetic prejudice at the outset of the Counter Reformation. In fact, as recent literature has pointed out, the modern era saw an increasing concern with the correspondence between belief and practice, 'moral distance between public forms of behavior and private thoughts and feelings', a 'correspondence' - in Aquinas' words quoted before - that religious patronage was sometimes aimed to bridge. ${ }^{30}$ In Renaissance Rome, however, this 'moral distance' was also embedded in more local polemics, and turned into a current topic of discussion, one in which Spain and hypocrisy would occasionally have been even interchangeable. In the Erasmus of Rotterdam quotation at the beginning of this article, the Dutch scholar made it into a refined formula. In a famous letter to Thomas More in 1517 explaining to his friend why he would turn down Cardinal Cisneros' offer to move to Spain to contribute to the Polyglot Bible, Erasmus

29 T. Aquinas, Summa Theologiae, IIa, IIae, q.111: 'Mala ergo intention in hypocrisi consideratur sicut signatum, quod non respondet signo. Exteriora autem vel verba vel opera, vel quaecumque sensibilia consideratur simulation et mendcacio sicut signa'.

30 Talal Asad, Genealogies of Religion: Discipline and Reasons of Power in Christianity and Islam (Baltimore: Johns Hopkins University Press, 1993), p. 67: 'when conventional behavior is seen as being essentially representational [emphasis mine] and essentially independent of the self, the possibility is opened up of deploying it in games of power'. 
enigmatically concluded: non placet $I \sigma \pi \alpha \nu l \zeta \varepsilon(v) .{ }^{31}$ For such a reader as More, it wouldn't be difficult to understand Erasmus' word-play: ispanizein - to be among or behave like a Spaniard - echoing, I would suggest, the word iudaizein, a verb coined by St Paul (Gal 2.14) for those who, being Jewish converts, remained imprisoned in a legalistic understanding of religion. ${ }^{32}$ Spanish Christian religion, it seems Erasmus was ironically implying, had only reached the flesh of the rituals, but not the spirit of a true conversion.

From this understanding of Spanish society as being deeply semiticized to considering their ritualistic practice of religion as a sign of hypocrisy, there was only a short step that Italians would prove eager to make. Fifteen years later, in Rome, accusations of hypocrisy had become endemic. In 1532 Juan Ginés de Sepúlveda, a member of Carlos V's court just like Ferrante Gonzaga, published his Latin Antiapologia defending Alberto Pio against Erasmus of Rotterdam. ${ }^{33}$ The year before, the former had denounced the Dutch Humanist's attacks on religious Catholic rituals and practice, with special attention to images. Joining now the Prince of Carpi, Sepúlveda challenged Erasmus to stand on his accusation that this was all about hypocrisy, 'for who is ignorant of the fact that the Greek hypocrisy means nothing other than the Latin histrio or simulator?' ${ }^{4}$

Painting being a major instrument in the construction of public religious identity, it is not surprising that art criticism frequently turned to this aspect of moral 'simulation'. Aretino, in fact, had not been the only one to make use of the term as a derogatory aesthetic judgment. In the $155^{\circ}$ edition of his Lives of the Artists, for example, Giorgio Vasari used it to describe the style of Giovanni Antonio Sogliani, whose devout and pious compositions (Vasari claims that he

$31 \quad$ Erasmi Roterodami, Opus Epistolarum, III, Ep. 628. Also cited by Marcel Bataillon, but while he insisted on Erasmus' anti-judaic prejudices, he overlooked his irony: M. Bataillon, Erasmo y España. Estudios sobre la historia espiritual del siglo XVI (Madrid: Fondo de Cultura Económica, 1991 [1966]), p. 77.

For the cultural and hermeneutical consequences of such a trope, see David Nirenberg, 'Figures of Thought and Figures of Flesh: 'Jews' and 'Judaism' in Late-Medieval Spanish Poetry and Politics', Speculum, 81 (2006): pp. 398-426, now also in Neighboring Faiths: Christianity, Islam and Judaism in the Middle Ages and Today (Chicago: University of Chicago Press, 2014), pp. 117-41.

33 See on this episode, Nelson H. Minnich, 'The Debate between Desiderius Erasmus of Rotterdam and Alberto Pio of Carpi on the Use of Sacred Images', in Annuarium historiae conciliorum. Internationale Zeitschrift für Konziliengeschichtsforschung, 20 (1988): pp. 379413 .

34 Juan Ginés de Sepúlveda, Antiapología en defensa de Alberto Pío frente a Erasmo de Rotterdam, in Obras completas (Pozoblanco, Cordoba: Ayuntamiento, 2003 [1532]), vol. 7, p. 144 . 
greatly admired Fra Bartolomeo) were secondo l'uso de gli ipocriti ('following the use of hypocrites'). ${ }^{35}$ Like Sebastiano's critics, Vasari also paired the term with that of devoto or 'devotional', one that he used almost exclusively to describe the pious work of the Dominican painter Fra Angelico, now beatified, an artist to whom Counter-Reformation critics continuously turned when looking for a model that would reconcile artifice with religious decorum. ${ }^{36}$ It is not a coincidence that the largest cycle of Fra Angelico's Roman frescoes those that have unfortunately now disappeared at Santa Maria Sopra Minerva - had been the commission of a Spanish prelate, none other than the converso cardinal Juan de Torquemada. ${ }^{37}$ Although better known for being the uncle of the famous Inquisitor, Torquemada was a skilled theologian who extensively polemicized on the status of religious images with Jews and Muslims, on the one hand, but also wrote against the Hussites on this same matter. ${ }^{38}$ In his writings, Torquemada not only turned his eyes to the mosaics of the early Christian church, and the image-relics preserved in the city, he also relied on Thomas Aquinas for defending the highest degree of veneration for religious images. It had been to Fra Angelico, and later to his follower Antoniazzo Romano, that Spanish patrons had usually turned in Rome when looking for a devout style that one late fifteenth-century contract for San Giacomo degli Spagnoli describes as Ad modum Yspaniae. ${ }^{39}$

35 'Fu persona che viveva con religion ... La maniera sua molto piacque allo universal, faccendo egli arie pietose e devote, secondo l'uso de gli ipocriti'; Giorgio Vasari, Le Vite de' più eccellenti architetti, pittori, et scultori italiani da Cimabue, insino a' tempi nostril. Nell' edizione per i tipi di Lorenzo Torrentino, Firenze 1550 (Torino: Einaudi, 1986), vol. 2, p. 761.

$3^{6}$ Fra Angelico's popularity in Counter-Reformation Spain has been beautifully reconstructed by Falomir, 'Dono italiano'.

37 See for these, Gerardo di Simone, 'L'ultimo Angelico. Le Meditationes del cardinal Torquemada e il ciclo perduto nel chiostro di S. Maria sopra Minerva', Ricerche di Storia dell'arte, 76 (2002): pp. 41-87; Angi L. Elsea, Reconstructing the Lost Frescoes of Santa Maria sopra Minerva in Rome from the Meditationes of Cardinal Juan de Torquemada (Lewiston: Eldwin Mellen Press, 2009). For Torquemada's commissions from Angelico, see also Miklos Boskovits, 'La fase tarda del Beato Angelico, una proposta di interpretazione', Arte Cristiana, 71, no. 694 (1983): pp. 11-24.

38 For Torquemada's writing on images, see F. Pereda, Las imágenes de la discordia. Políticay poética de la imagen sagrada en la España del cuatrocientos (Madrid: Marcial Pons, 2007), pp. 237-38, pp. 408-10 (forthcoming English translation). For his polemic against the Hussites, see Reprobationes triginta octo articulorum quos tenant usiti de moldavis, Biblioteca Apostolica Vaticana, Vat. Lat. 976, fols. 71-94. I don't know of any literature on this very interesting document. 
Spanish interest in devotional painting, however, might have seemed paradoxical in the eyes of Roman viewers: in 1498, the same bishop responsible for the renovation of San Giacomo in Piazza Navona (from where this panel comes) was tried in Rome for heresy in a public auto de fe. Along with the charges of anti-trinitarianism, or praying more ebraico, Pedro de Aranda, as he was named, was accused of rejecting religious images and even of having them destroyed, calling them immunditias et tristitias. ... ${ }^{40}$ I will go back to this paradox in a moment, but I must briefly return first to the Aretine critic.

'Hypocrisy' would become a major concern of Aretino in the following years, ${ }^{41}$ as well as a source for literary inspiration, exactly at the same pace as the religious climate paved the way towards the Counter Reformation in Italy. In his satirical dialogue Raggionamento delle corti (1538), two of the most relevant protagonists of this process and, in the words of Christopher Cairns, Aretino's 'two great ecclesiastical enemies', were made his targets: Gian Pietro Carafa, later Pope Paul IV, and the famous Cardinal of Verona, Gian Mateo Giberti. ${ }^{42}$ It is certainly not a coincidence that both religious reformers developed similar policies against the demonstration of visual signs of the Passion in sacred images: as a part of his program of ecclesiastical reform in the dioceses of Verona in the 1520s, Gian Mateo Giberti ordered that excessive blood

ment) that such a term refers to a pictorial mode, as argued in Fernando Marías, El largo Siglo XVI. Los usos artísticos del Renacimiento español (Madrid: Taurus, 1989), p. 98; or as an iconographic reference, in Falomir, 'Sebastiano e il 'gusto spagnolo'. On Antoniazzo, see now S. Petrocchi and A. Cavallaro (ed.), Antoniazzo Romano. Pictor urbis 1435-1440/1508 (Rome: Silvana, 2013).

40 Anna Foa, 'Un vescovo marrano: Il proceso a Pedro de Aranda (Roma, 1498)', Quaderni Storici, 99 (1998): pp. 533-51. See also Foa, 'Converts and conversos in Sixteenth-Century Italy. Marranos in Rome', in The Jews in Italy: Memory and Identity (Bethesda: University of Maryland Press, 2008), pp. 109-29. Also Stefania Pastore, Ilvangelo e la spada. L'Inquisizione di Castiglia e I suoi critici (1460-1598) (Rome: Storia e Letteratura, 2003), pp. 79-80. On the Inquisition attention on newly-converted's attitudes towards images, see Pereda, Las imágenes de la Discordia; Pereda, 'Through a Glass Darkly: Paths to Salvation in Spanish Painting at the Outset of the Inquisition', in Judaism and Christian Art: Aesthetic Anxieties from the Catacombs to Colonialism (Philadelphia: University of Pennsylvania Press, 2011), pp. 263-90.

41 'the theme of hypocrisy was a constant leitmotiv during Aretino's Venetian period', Christopher Cairns, Pietro Aretino and the Republic of Venice. Researches on Aretino and his Circle in Venice 1527-1556 (Firenze: Leo S. Olschki, 1985), p. 179.

42 Cairns, Pietro Aretino, p. 77. 
should be erased in representations of the Crucifixion. This, he argued, was against the understanding of Christ's triumphant glory. ${ }^{43}$

For his part in 1556, Paul IV Carafa ordered that crucifixes should have no more than quattro piaghe (four wounds), again limiting the excessive signs of the Passion in iconography. ${ }^{44}$ Scripture, and not popular imagination, was to reestablish the limits of decorum. Sebastiano's strategy for Francisco de los Cobos follows a similar path: his painting blurred the pain of the passion while at the same time not only employed one of the most traditional types of Christian devotional painting, but also underlined its reference to the foundational sacred models of this tradition. At this point I need to correct what I think has been a continual misunderstanding of the painting's iconography. The depiction of the Pietà as part of a narrative scene at the sepulcher is certainly not new in the pictorial tradition. Having the Virgin Mary, however, holding an imprint of Christ' face on a cloth is. Traditionally art historians have solved this narrative inconsistency by appealing to the devotional or transhistorical nature of the painting. This is however, in my opinion, hardly necessary.

\section{Veronica or Sudarium? A Note on Iconography}

Sebastiano's representation of the Pietà is not only justified by Scripture, but also by the iconographic tradition, even if one needs to go back in time to find eloquent comparisons. As a matter of example, in the miniature from the Ottonian Gereon Sacramentary [see fig. 13.6], the Virgin finds two different pieces of cloth at the tomb: one wrapped around the tomb's border, and another much smaller one which she holds in her hands, pressing it to her face. This is obviously consistent with Scripture - according to John 20: 6-8, a linen cloth or linteamina and also the square sudarium covering only Christ's face were found at the empty tomb - and it is frequent to find the separate representation of both pieces of cloth in Christian iconography (from early Ottonian miniatures to Fra Angelico), either as a square blank piece of cloth or even

Antonio Fassani, Riforma pretridentina della diocese di Verona: Visite pastorali del vescovo G.M. Giberti 1525-1542 (Vicenza: Istituto per le ricerche di storia sociale e di storia religiosa, 1989), p. cxxx. Also in Nagel, 'Experiments in Art'.

Paul IV, bull of 1556, in Antonio Carracciolo, Vita et gestis di Giovan Pietro Carafa cioè di Paolo IV (Naples, 1619), Biblioteca Casanatense, ms. 349, fols. 392r-v. I thank Pierroberto Scaramella for the reference, and Hannah Friedman for checking it for me. 
imprinted with Christ's face. ${ }^{45}$ While in the sixteenth century the independent portrait of Christ recalled of course Veronica's relic in Rome along with its medieval legend, Sebastiano's insertion and re-framing of Christ's portrait in the place and time of Christ's entombment immediately forces its identification with the funerary sudarium. ${ }^{46}$

This reconsideration is not only meaningful as an effort to replace fiction with the truth of history - in fact none other than Calvin himself used Scripture to undermine both the authenticity of the Veronica as well as the pretended full-length sudarium, the Holy Shroud -47 but also to find a balance between the narrative and iconicity that emphasized pictorial evidence: as recorded in John 20:6-8 it was the proof provided by this discovery that convinced Peter and John that the resurrection had really taken place: vidit et credidit, "he saw and believed', in John's words; no doubt one of the strongest affirmations of visual recognition, or autopsy, in the Gospels. ${ }^{48}$ At a moment when the author-

45 Trond Lectionary (Liège, 1160-80). Morgan Library, 883, fol. 51v; Book of Hours, Dutch, early fifeteenth. ms. Laud Lat. 15 Bodleian Library (Oxford).

46 As Von Dobschütz's collection of sources makes in fact clear, sudarium is the term most often used in early sources to refer to the Roman relic: Christusbilder: Untersuchungen zur christlichen Legende (Leipzig, 1899), p. 221 n. 8, p. 279 n. 10 n. 11, n. 15, n. 16, and so on. For the early history of the Veronica see Jean-Marie Sansterre, 'Variations d'une legend et genèse d'un culte entre la Jérusalem des origines, Rome et l'Occident', Passages. Déplacements des hommes, circulation des textes et identités dans l'Occident médiéval (Paris: Méridiennes, 2013), pp. 217-31. Sansterre discusses the emergence of the Veronica cult in competition with the Lateran sudarium of which there is nothing not but literary traces. The historical confusion or overlapping of these two relics, or their textual referents has not as far as I know been the object of consideration.

In his Traité des reliques (1543), Calvin not only dismissed the Veronica for its lack of Scriptural basis, he also discussed the authenticity of the Holy Shroud (at the time not yet in Turin) for not corresponding with John's description of the square sudarium: 'Ce que aussi l'évangéliste exprime, quand il dit que saint Pierre vit les linges d'un côté, où le corps avait été enveloppé, et d'un autre côté le suaire, qui avait été posé sur la tête. Car telle est la signification de ce mot de suaire, de le prendre pour un mouchoir ou couvre-chef, et non pas pour un grand linceul qui serve à envelopper le corps. Pour conclure brièvement, il faut que l'évangéliste saint Jean soit menteur, ou bien que tous ceux qui se vantent d'avoir le saint suaire soient convaincus de faussetés et qu'on voie apertement qu'ils ont séduit le pauvre peuple par une impudence trop extreme'; Jean Calvin, Traité des reliques suivi de l'excuse à messieurs les Nicodémites (Paris: Bossard, 1921), pp. 129-30.

48 Richard Bauckham, Jesus and the Eyewitnesses: The Gospels as Eyewitness Testimony (Cambridge: Eerdmans, 2006); Samuel Byrskog, Story as History, History as Story: The Gospel Tradition in the Context of Ancient Oral History (Leiden: Brill, 2002), are exemplary analyses of this aspect. 


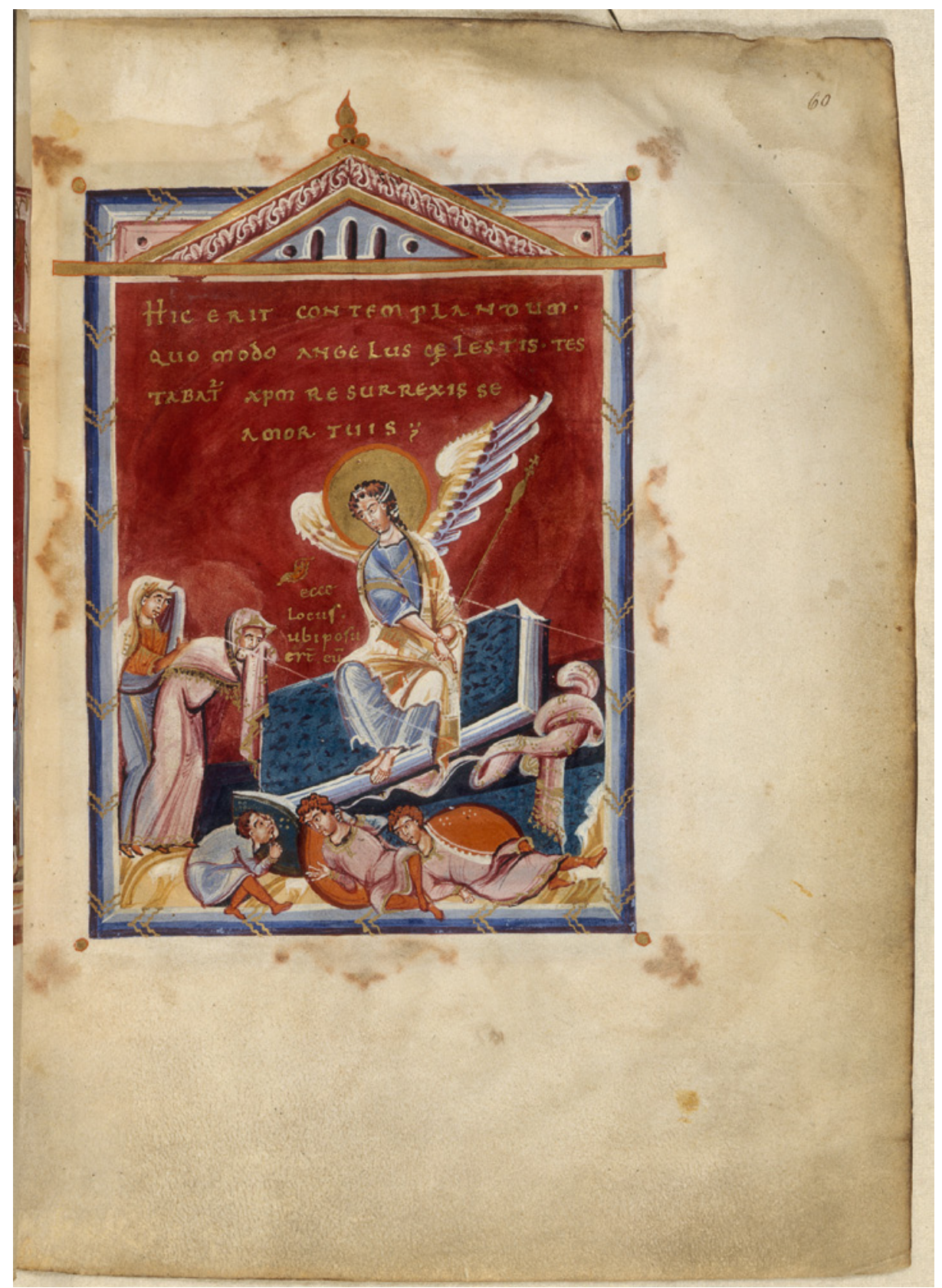

FIGURE 13.6 'Maries at the Sepulchre', Sacramentarium Sancti Gereonis Coloniensis, Lat. 817, Bibliotheque Nationale, Paris, Île-de-France. 
ity of image-relics was debated and questioned, Sebastiano seems to have deliberately chosen to emphasize the evangelic tradition of image-making.

That the Venetian painter Sebastiano acted in a way to please both his patron, Ferrante Gonzaga, and the final addressee of the painting, Francisco de los Cobos, has left extensive evidence in the correspondence that crossed between the patron and his Roman agent until its final delivery in 1539. As I have already established, hypocrisy as an aesthetic and moral prejudice was spreading in mid-sixteenth century Italy, but it also had a much more local, if not xenophobic component to which it is urgent now to turn our attention. If in the already-mentioned satire against Hypocrisy, the Raggionamento delle corti, Aretino had made his friend, the poet Ludovico Dolce, a character in his dialogue, some years later, Dolce turned him into the protagonist of his famous dialogue L'Aretino, named of course after his memory, a major text of Renaissance art criticism.

As a character of Dolce, Aretino expresses here again his disapproval of Sebastiano del Piombo, but now in a much more specific and at the same time enigmatic way. When discussing Ariosto's ranking of painters, in which Sebastiano del Piombo had been placed at the top, sharing the place with Raphael and Titian, Aretino expressed his strong opposition to comparing him with either of these two painters. Immediately afterward, Aretino added: 'such a peccadillo (to use a Spanish term here) does not keep Ariosto from having been that perfect poet that the world adjudges him to be. 49

That the pecadillo was a familiar term in the world of Venetian painters is proved by Paolo Pino. Nowhere but in his Dialogo de la pittura (1548) does Pino refer to the pecadiglio dell'Hispagnuolo, in his use, a euphemism that masks with a diminutive the gravity of a serious error. ${ }^{50}$ To know what offensive mistake they were referring to, it is worth asking Ludovico Ariosto himself. In his Satira a Bembo, the author of the Orlando Furioso put it plainly: Et oltra questa nota, il peccadiglio / di Spagna gli dànno anco, che non creda/in unità del Spirito il Padre e il Figlio (And also this, the Spanish pecadillo, which is of those who do not believe in the unity of the Holy Spirit, the Father and the Son). ${ }^{51}$

49 Mark W. Roskill, Dolce's Aretino and Venetian Art Theory of the Cinquecento (Toronto, Buffalo, London: University of Toronto Press, 2000), pp. 92-93.

'fornire il ragionamento vostro vi riman lo peccadiglio dell'Ispagnuollo, riposto da lui nel fondo della confessione come più leve, et era più grave che tutti gli altri insieme [emphasis mine]'; Paolo Pino, Dialogo della Pittura (Milan: Rizzoli, 1954). (Bari: Laterza, 1917); Arturo Farinelli, Marrano (storia di un vituperio) (Geneva: Leo S. Olschki, 1925); and Chapter 10 by Stefania Pastore in this volume. 
As Benedetto Croce made clear a century ago, Venetians, and more generally Italians, perceived Spaniards as incredulous - cases like the just-cited auto de fe of Pedro de Aranda no doubt contributed to it - but they also interpreted such incredulity as an indelible stain deeply rooted in Spain's recent history of multi-confessionalism and forced conversions. And they soon found a word for it: Spaniards - wrote Aretino's secretary Niccolò Franco - per non creder, si chiamano marrani ('because they don't believe, they are called marrani'). Even the previously-cited Ginés de Sepúlveda, writing in 1532, seems to have shared this criticism when, defending the friars' fondness for external expressions of piety, he argued that this should not be seen as an expression of 'superstitious judaizing. ${ }^{52}$

'Marranism' turned out to be a useful interpretive tool when it came to framing and also counteracting any form of infectious heterodoxy. It is not surprising therefore that it was soon applied to religious history and relics, the two subjects of our painting. In 1528, Count Baldassare Castiglione, the Mantuan agent of Pope Clement VII at the Castilian court, responded to Alfonso de Valdés' written defense of the Imperial responsibility for the Sack of the Holy City, recalling among other sad episodes, the way the Santo Sudario di Cristo [sic] had been 'stepped on and vilified' by those who called themselves faithful, the troops of the Emperor. ${ }^{53}$ It should come as no surprise that Castiglione identified Valdés' Erasmian critique of Roman 'superstitious' relics and images as a sign of his marranismo. And in fact, Valdés' Converso origins were very well known. 54

In conclusion, when only five years later, another Mantuan agent of Ferrante Gonzaga, this time in Rome, considered that Spaniards liked 'pious' painting per parer buon cristiani (to look like good Christians), he not only meant that such was their taste, as it has usually been argued, ${ }^{55}$ but he also implied that

\section{$5^{2} \quad$ See n. $3^{2}$.}

53 Baldassare Castiglione, 'Respuesta del Conde ... nuncio en España, a la carta de Valdés de agosto de 1528', in Alfonso de Valdés, Obra Completa (Madrid: Biblioteca Castro, 1996), pp. 540-74, esp. p. 551 .

54 See most recently Stefania Pastore, Un'eresia spagnola. Spiritualità conversa, alumbradismo e inquisizione (1449-1559) (Florence: Leo S. Olschki, 2004), p. 167ff. On the Italian reception of the Valdés brothers see Massimo Firpo, Tra alumbrados e 'spirituali' Studi su Juan de Valdés e il valdesianismo nella crisi religiosa del '50o italiano (Florence: Leo S. Olschki, 1990). For a reconsideration of these exchanges see James Amelang, 'Exchanges Between Italy and Spain: Culture and Religion', in Spain and Italy: Politics, Society and Religion 1500-1700, (ed.) Thomas Dandelet and John A. Marino (Leiden: Brill, 2007), pp. 433-55.

55 Starting with Michael Hirst's work on Sebastiano, this also applies to Spanish bibliography. 
painting had become one true mask of their less truthful religious convictions (whether he was right or not is of course another question). Whatever Francisco de los Cobos personally thought is of the little relevance. More important now, though, is on the one hand how this tension was played out in the pictorial field; and on the other what the broader cultural consequences were. I have briefly analyzed the sophisticated strategy followed by Sebastiano in his famous Pietà, but his was a fragile balance, and not always equally successful. Let us now dig further into this fascinating problem.

According to the same epistolary documentation that we have been using so far, Francisco de los Cobos visited Sebastiano del Piombo in 1539, and finally contemplated the finished painting. At his workshop, Cobos would have also seen a second painting that Sebastiano had finished, this time for the Count of Cifuentes, Carlos V's Ambassador in Rome. We do not know what Cobos thought of this other painting, but this one Sernini did not like at all:

If your Eminence had seen the Christ with a cross on his shoulder that he painted for the Count of Cifuentes you would have been very disappointed, because not only would you not have liked it, but it was offensive to look at (offendeva da vederlo). ${ }^{56}$

It is not difficult to imagine now what Sernini found so 'offensive' in the painting. Unlike in the Cobos Pietà, Christ's painful expression is here disturbing as the thorns of the crown penetrate into his forehead. It is interesting to note that the Portacroce was one of the most popular of all of Sebastiano's compositions in Spain, having been copied on multiple occasions, some even signed as originals of Sebastiano (like in the unpublished panel at the Descalzas Reales which is presented here for the first time) [see fig. 13.7]. ${ }^{57}$ At least one second copy, now in Ávila, preserved the authority of the model by giving acknowledgement to Sebastiano as its 'inventor'.58 The author of this last copy, the Portuguese painter Manuel Denís, has a peculiar significance to our discussion, as Denís is the translator of Francisco de Holanda's early criticism of Sebastiano's style, the famous Dialoghi romani, in which the Venetian is described as desmelanconizado, a term that according to Covarrubias means something like 'non saddening' or 'non grieving', lacking pathos, a restraint of

56 Hirst, 'Sebastiano's Pietà'.

57 Inv. 00610683. I thank Ana García Sanz for helping me identify this painting.

58 María José Redondo Cantera y Vitor Serrâo, 'El pintor portugués Manuel Denís, al servicio de la casa real', in El arte foráneo en España. Presencia e influencia (Madrid: Departamento de Historia del Arte, IH-CSIC, 2005), pp. 61-78. See also Falomir, 'Sebastiano del Piombo'. 


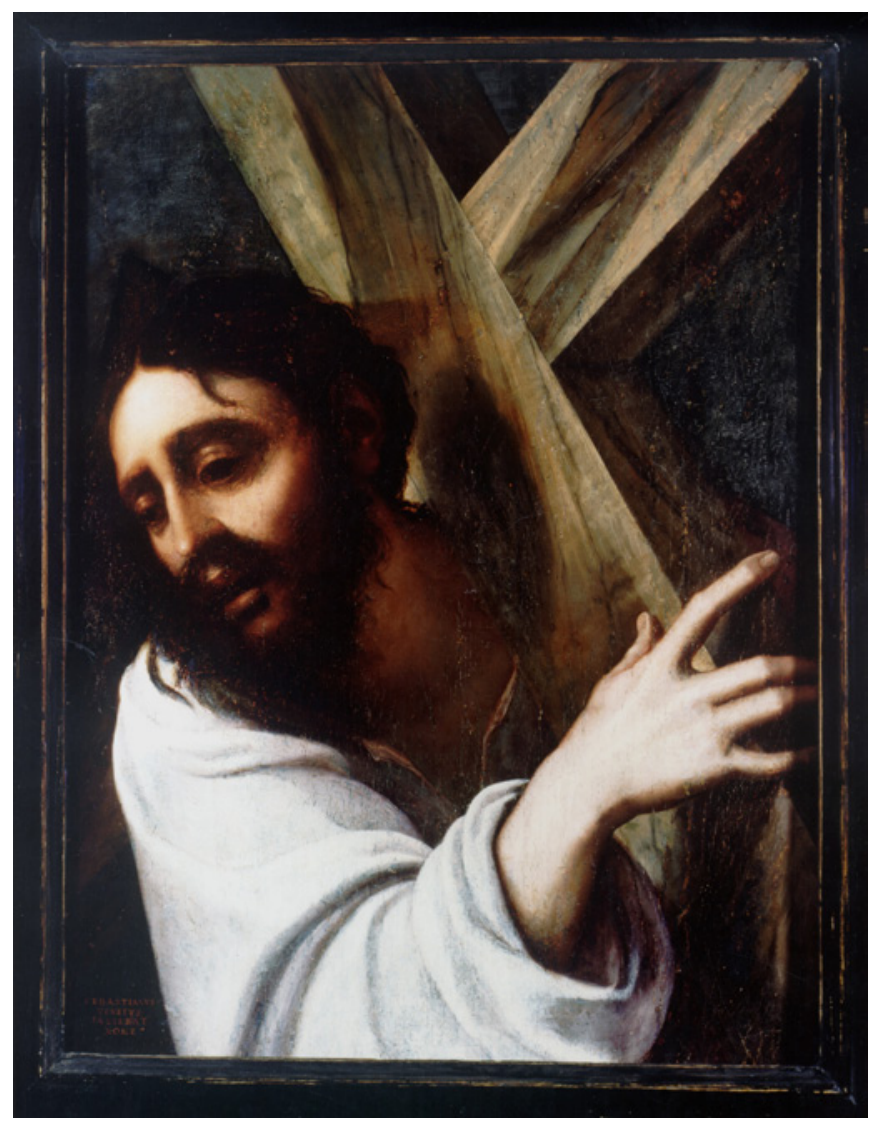

FIgURE 13.7 Sebastiano del Piombo, (copy of) Christ carrying the Cross, Monasterio de las Descalzas Reales. Patrimonio Nacional, Madrid.

expression for which his Spanish interpreters would be eager to compensate. ${ }^{59}$

59 Francisco de Holanda, De la pintura antigua seguido de 'El diálogo de la Pintura'. Versión castellana Manuel Denís (1563) (Madrid: Visor, 2003), p. 186. Unfortunately, we cannot be sure about the exact words that Denís translated, as the original manuscript - copied in Madrid in the nineteenth century - has disappeared. Two opposing versions circulate: according to one [based on Joaquim de Vasconcelos (ed.) Vier Gespräche über die Malerei geführt zu Rom 1538 (Vienna, 1899), p. 96] the original said muito desmanencolizado a beautiful and eloquent neologism [Holanda, Da Pintura Antiga, Portuguese edition by A. González García, (Lisbon: Imprensa Nacional, Casa da Moeda, 1983), p. 289]. This I take as the most probable. For reasons not explained in the paratext, a recent edition of the Portuguese text says just the opposite: muito melancólico [Holanda, Dialoghi di Roma (Roma: Bagatto, 1993), p. 140]. Most puzzling is the recent English translation: 'the very carefree 
This process is better seen in the interpretation of Sebastiano's Portacroce trademark by the more gifted painter Luis de Morales. Here, however, with interesting changes with which I would like to conclude.

\section{Inventive Reception: The Case of Luis de Morales}

The reception of Sebastiano del Piombo's paintings in Spain was extraordinary, deeper maybe than any other Italian artist of the Renaissance and more long-lived, enduring well into the Baroque [see fig. 13.8].$^{60}$ Extensively interpreted and copied, his models were subject to certain significant changes precisely where Sebastiano's religious 'signs' had remained blunted, if not ambiguous. The earliest copy of the 'Cobos Pietà' that we know of brings us back to the beginning of this study. It is a small panel of the exact measurements of its model, dated circa 1550 and attributed to Martín Gómez el Viejo (d. 1562), the same artist with whom Esteban Jamete collaborated in the altarpiece mentioned at the beginning of this article [see fig. 13.9]. ${ }^{61}$ The panel's provenance is the Inquisitiorial jail of Cuenca, the very same in which Jamete was confined between 1557 and 1559, although there is no reason to consider this more than a disturbing coincidence. The painter has rendered evident what in the original is only suggested: the size of the nails, the tears on the Virgin's face and, more than anything, the blood flowing from Christ's wound.

Much more interesting, though, is the way Sebastiano's model was reinterpreted by the painter who was arguably the most gifted at Spanish passion iconography, the just-mentioned Luis de Morales (ca. 1570, Academia de Bellas

Sebastiano ...' [Holanda, On Antique Painting, (trans.) Alice Sedgwick Wohl (Pennsylvania: Penn State University Press, 2013), p. 206]. Manuel Denís' response, in any case, would be then aligned with later Counter-Reformation responses, such as those of Giovanni Andrea Gilio ['Dialogo nel quale si ragiona degli errori e degli abusi de' pittori circa l'istorie, 1564', in Trattati d'arte del Cinquecento. Fra Manierismo e Controriforma, (ed.) Paola Barocchi (Bari: Laterza, 1961), p. 40], or Antonio Possevino, Tractatio de poesi et pictura ethnica, humana et fabulosa collata cum vera, honesta et sacra (Rome, 1594), book XVII, p. 545, both of which criticized the whips at the flagellation in the Borgherini Chapel, which seemed made of 'soft wool' instead of hard matter.

6o From Juan de Juanes ('Christ with Angels', Dallas Museum of Art) to Francisco Ribalta (Madrid, Museo del Prado). See F. Benito Domenech, Los Ribalta y la pintura Valenciana de su tiempo (Madrid: Museo del Prado, 1987), pp. 146-47.

61 Pedro Miguel Ibáñez Martínez, Pintura conquense del siglo XVI (Cuenca: Diputación Provincial, 1993). There is an abundant number of early copies of the Cobos Pietà in Spain. See some of these collected in Benito, 'Sebastiano del Piombo', p. 75. 


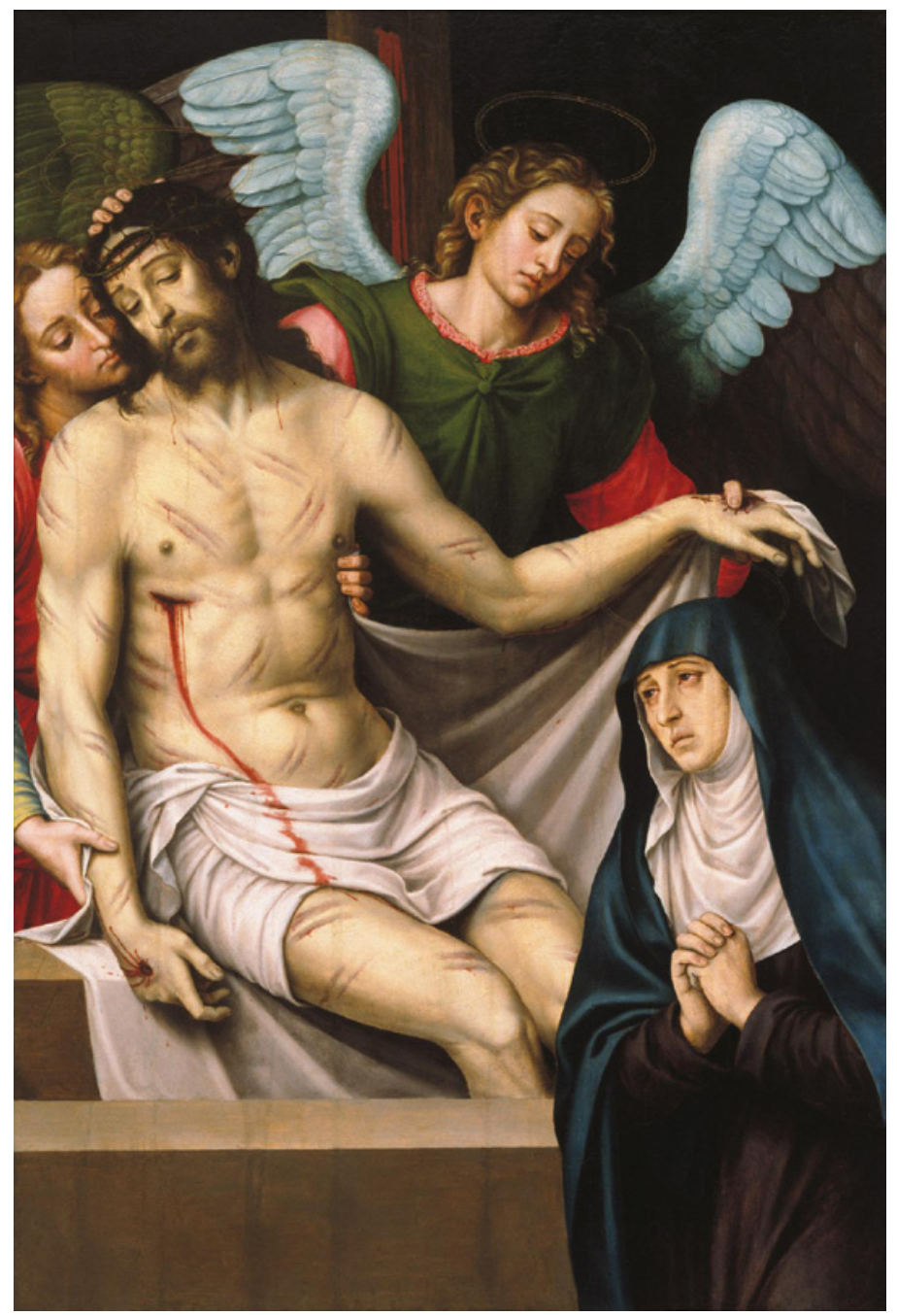

FIGURE 13.8 Juan de Juanes (d. 1579), Christ with Angels, 153.67 × 102.87 cm, oil on panel. Dallas Museum of Art.

Artes de San Fernando, Madrid), a formal ascendancy that, as far as I know, has received no attention [see fig. 13.10]. ${ }^{62}$ Morales' dependence on Sebastiano is as deep and as significant as his deviation from his model. His famous Piedad

62 There are two more versions of the same composition, one autograph at the Louvre (Paris), and a second one in Caen. The one in the Academia (Madrid) was previously in the posession of the Jesuits in Cordoba; Ingjald Bäcksbacka, Luis de Morales (Helsinki: Helsingfors, 1962), p. 113 . 


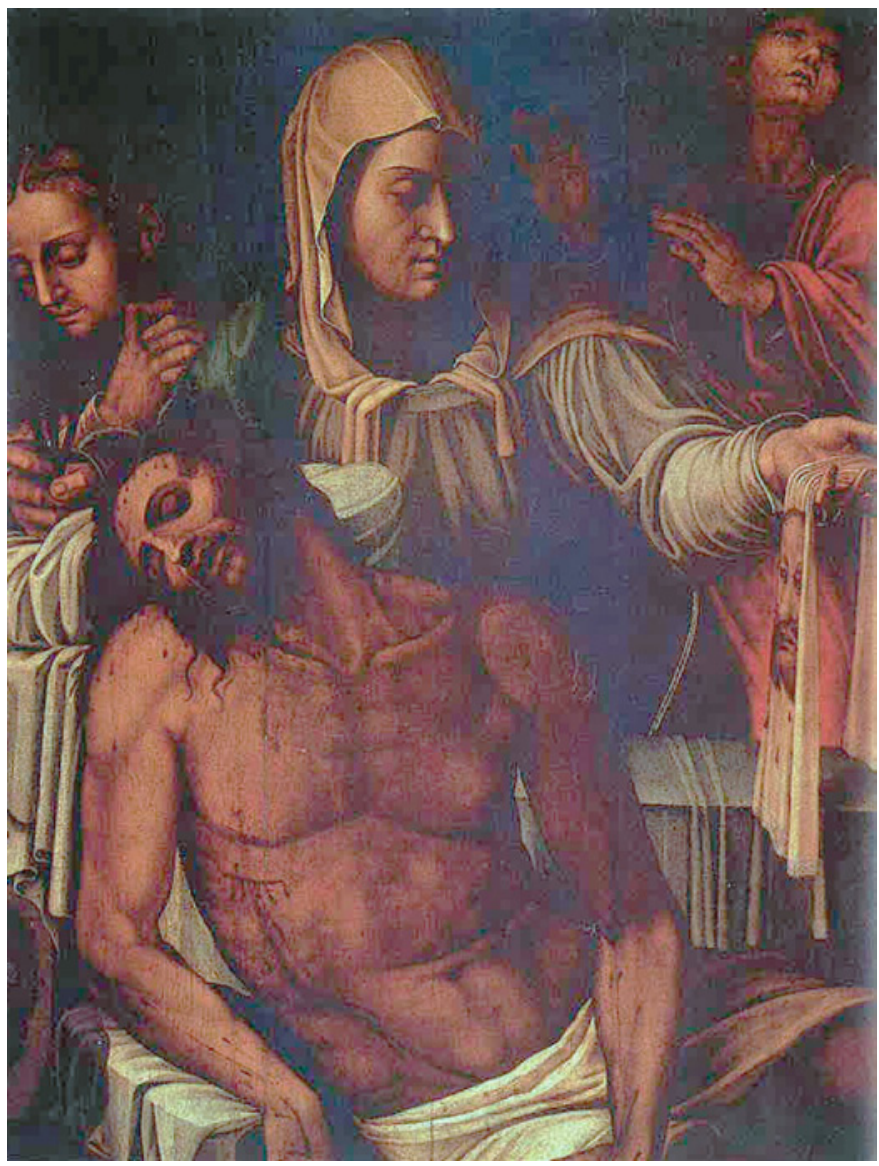

FIgure 13.9 Martín Gómez el Viejo (d.1562), 'Piedad', Ministry of Justice (Madrid). Provenance: Inquisition Jail (Cuenca).

departs from Sebastiano's emotional control into dramatic expression; from psychological detachment into physical engagement. ${ }^{63}$ The comparison between the two panels creates an eloquent contrast: at the same time a close dependence and yet a very different sensibility. Morales has pushed the closeup even further towards the viewer, situating the group in between us, the viewers, and the cross raising up directly behind the figures. The physical and emotional distance between Mary and her Son has been suppressed, and it is

63 For Luis de Morales, Bäcksbacka, Luis de Morales; see Carmelo Solís Rodríguez, Luis de Morales (Badajoz: Fundación Caja Badajoz, 1997). Efforts to frame Morales' painting in the context of Spanish early modern spirituality include Marías, El largo siglo XVI, pp. 340-49; see Alfonso Rodríguez G. de Ceballos, 'El mundo espiritual de Luis de Morales', Goya, 196 (1987): pp. 194-203. 


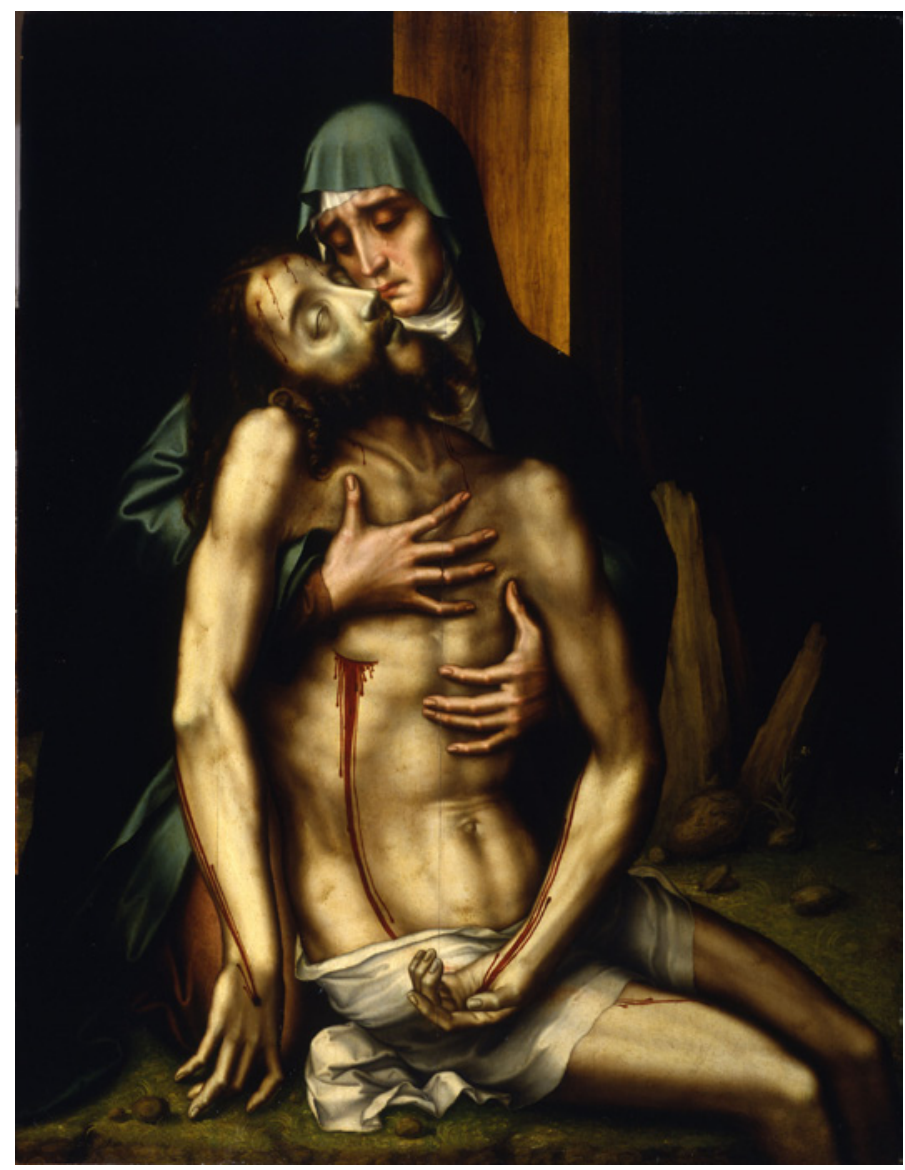

FIgure 13.10 Luis de Morales, 'Piedad'. Madrid, Museo de la Real Academia de Bellas Artes de San Fernando.

now the Virgin who painfully holds Christ's emaciated, lifeless body. Some details, however, betray its origin: besides the general composition, Christ's left arm, for example, still remains identical to Sebastiano's. In order to reformulate his invention, Morales then looked for alternative models. Interestingly enough, he did not find them in Flemish art, but in Italian. Morales seems to have combined Sebastiano's composition with the next most authoritative referents of this iconography, both from Michelangelo. Certainly he drew upon the Virgin della febbre - which he could have studied in any of its early prints - but maybe also the Florence Pietà. ${ }^{64}$ In Michelangelo's Pietàs Morales found

64 Bernardine Barnes, Michelangelo in Print: Reproductions as Response in the Sixteenth Century (Farnham: Ashgate, 2010). The exact position of the twisted arm seems to evoke even more clearly the Florentine Pietà; however, no print is known previous to the painting. 


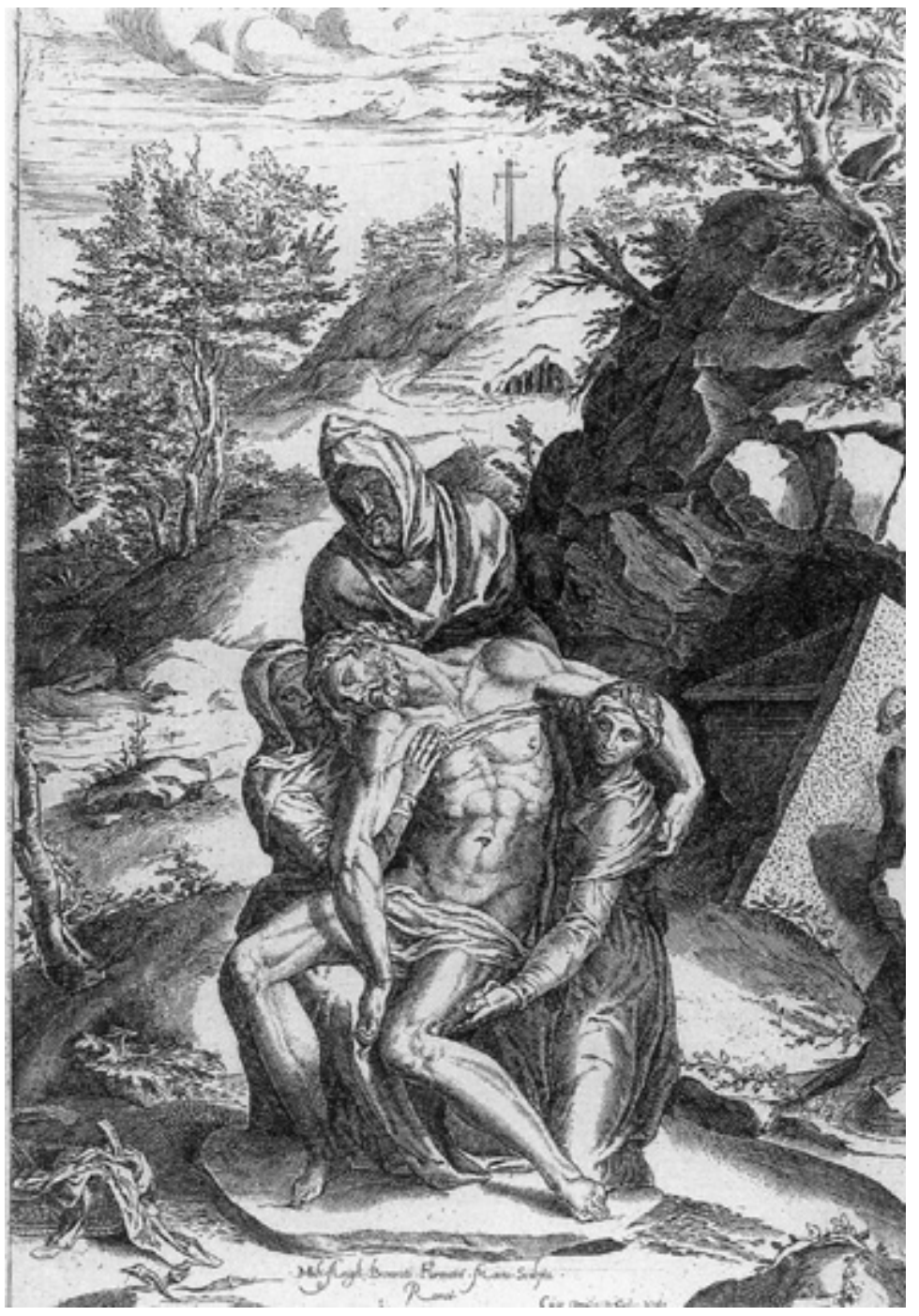

FIGURE 13.11 Michelangelo, 'Florentine Pietà.' Engraving (Rome, 1566).

a convincing solution for the Virgin holding the dead body from the ankle and the head of Christ falling backwards on his shoulder; in the Florentine sculpture (again as translated most probably in a print) its particular twisting, and even the position of Nicodemus looking diagonally to the corpse [see fig. 13.11].

Unlike in any of these two models, however, Morales had Mary's hands completely embrace Jesus, holding his corpse tight as possible to her own body, showing even His flesh receding under the pressure of her fingers. Another 
striking contrast comes from the penitential signs of the passion: the tears on the Virgin's cheeks and the blood running neat and clean along Christ's forearms, side and forehead. The composition turns into a sophisticated tour de force, reaching the highest emotionalism possible while at the same time allowing the Virgin to maintain her moral dignity. It is as if Morales had worked to transform the ungrieving desmelancolizado Sebastiano del Piombo - in the term used by Manuel Denís - to produce a highly expressive icon.

\section{Mary at the Foot of the Cross}

Morales' painting is striking, no doubt one of the most successful inventions of Spanish devotional painting. Its economic composition and critical appropriation of Michelangelo's models, envision a complex emotional drama. This can only be fully grasped when seen against the context of the debate on Mary' performance at the foot of the cross, a debate that was inextricably devotional, political and at the same time artistic in mid-sixteenth century Italy and Spain.

Again Jamete's Inquisitorial deposition allows us to step into the argument. During his trial, the French artist was suspected of having complained that some painters represented the Virgin overwhelmed by the pain, fainting into John' arms, and not 'with great dignity' (estuvo con grán ánimo) as they should. Jamete argued (wrongly, in the eyes of the Inquisitors) that Mary remained still, contemplating her son's 'labors' ... 'because only in her son's deeds remained her faith' (porque en ellos sola quedó la fe). ${ }^{65}$ His remark is far from naïve: Jamete's dismissal of that precise iconography was articulated, as we can see, as a polemical rejection of Mary's co-redemption. ${ }^{66}$ Interestingly enough, Jamete tried to get around the Inquisitor's suspicion by citing as his source a book on the life of Christ written in none other than Antonio de Guevara's

65 'fallo alli un libro que se llama Monte Calvario e que el leyo que decia que al tiempo de la passion de $\mathrm{N}^{\mathrm{S}} \mathrm{Sr}$ quando le pusieron en la cruz y su madre $\mathrm{N}^{\mathrm{a}} \mathrm{S}^{\mathrm{a}}$ la Virgen Maria que estava presente e veía como le crucificavan que no cayo de su estado sino que siempre estuvo con gran animo e contemplando los trabajos de su hijo porque en ellos sola quedo la fe [emphasis mine] aunque aca en las pinturas que se fazen de aquel auto la pintan cayda en los brazos de San Juan e no tiene otro mas que dezir ny declarar ny se acuerda de otra cosa'. Domínguez, Proceso Inquisitorial, p. 31.

66 As beautifully demonstrated by Otto von Simson, 'Compassio and Co-redemptio in Roger van der Weyden's Descent from the Cross', The Art Bulletin, 35 (1953): pp. 9-56. See also Amy Neff, 'The Pain of Compassio: Mary's Labor at the Foot of the Cross', The Art Bulletin, 80 (1998): pp. 254-73. 
best-seller Libro del Monte Calvario, in which, however, consistent with sixteenth-century remarks on the problem, the Emperor's confessor emphatically defended the opposite: according to Guevara, Mary had fainted because of her unbearable suffering. ${ }^{67}$

Jamete's failed argument of defense was only possible because of the unclear position of the Church regarding this particular lack of consistency between Church teachings and artistic practice. This is a problem that deserves more attention than I can devote in these pages, but let me summarize the basic elements of the debate. Mary's swoon had been an object of discussion in years previous, and Julius II had even asked Cardinal Cajetan to investigate the case, resulting in a 1506 decree (republished 1529) that considered it inappropriate both on scriptural and theological grounds to celebrate the feast of her Spassimo: this was a violation of Mary's physical dignity and moral perfection. 68 The recommendation was very much ignored both in Italy and Spain, where the swooning of Mary continued to be a regular element of deposition scenes well into the sixteenth century. ${ }^{69}$ But it does not seem it was that reasoning that made Jamete feel uncomfortable with the paintings. While for Cajetan her collapse would have been a 'bodily defect' incompatible with her state of grace (Uke 1), the French artist arrived at a similar conclusion using different, if not even opposite arguments. What he argued was that the representation of an overwhelming pain equated her suffering to Christ's suffering, placing on her painful labor a redemptive value that 'only' (solo) corresponded to her Son. So if Jamete shared with Cajetan the critique's target, but not its reasoning, where did he get it from? Erasmus in my opinion is the strongest candidate.

The debate over Mary's swoon had been reopened in the following years by the Dutch humanist, now in terms that insistently considered the visual evidence. Erasmus' remarks (however they might have arrived to Jamete's knowledge) seem to be echoed by those of Jamete during his trial. His lengthy comment on Mary' attitude at the foot of the cross came as a response to his

67 Mary's swoon is extensively discussed in chapter xliii [Antonio de Guevara, La primera parte del libro llamado Monte Calvario (Valladolid: Sebastián Martínez, 1552), fol. 8ov: 'juntamente se yva el cielo anublando ... el hijo de Dios se muriendo, y la triste madre desmayando ... al pie de la cruz estaba cayda']. The Monte Calvario was published 1542, 1545, $1546,1548,155^{0}$ and subsequently. The Italian translation went through 14 editions, 155575 .

68 Harvey E. Hamburgh, 'The Problem of Lo Spassimo of the Virgin in Cinquecento Paintings of the Descent from the Cross', Sixteenth Century Journal, 12 (1981): pp. 45-75.

69 An exception might be Pontormo's Deposition, as analysed by Leo Steinberg, 'Pontormo's Capponi Chapel', The Art Bulletin, 56 (1974): pp. 385-99. 
Sorbonne censors. In his edition of the Gospel of Luke (27), the Rotterdam humanist was censured for writing that Jesus wanted His death to be non lugubrem, sed gloriosam, as was clear from His response to the crowd of women that escorted him lamenting and weeping on their way to Calvary. Turning to them, Jesus had said: 'do not cry' (nolite flere), ${ }^{70}$ what Erasmus understood as an invitation not to share in His suffering, but on the contrary, to take it as an instance for adoration, as His sacrifice was performed for the salvation of humanity.

The censure of the Sorbonne's theologians gave him material for a lengthy digression of which only the last section interests us at this moment. In it, the humanist strongly opposed those 'stupid artists' who showed the Virgin overwhelmed with grief when in fact they should be expressing her gaudium, or joy, for her Son's redemptive sacrifice. The macabre (lugubrem) representation of the Virgin at the foot of the cross was also strongly rejected by Erasmus as the product of the artists' invention,

especially in panels and sculptures, represented in the most miserable way, and not taken from the evangelic histories, but from the artists' imagination. And in this manner, they paint the mother of Jesus swooned at the foot of the cross collapsing to death, although if protested by Chrysostomus. And these same [artists] paint her [heart] pierced with seven swords. To this kind of images weep and sigh the unlettered (idiotae). But the same would equally cry if they were to see Euripides' Hecuba. ${ }^{71}$

For the larger problem of Erasmus (and other Reform theologians) on the joyous celebration of Christ's death, see Michael A. Screech, Laughter at the Foot of the Cross (London: Penguin, 1997).

'Videmus interdum in spectaculis, cum per homines etiam leves repraesentatur mors Christi, quibusdam praesertim mulierculis erumpere fingultus ac lacrymas. Idem efficiunt picturae etiam mendaces, veluti quae repraesentant Christum novies collapsum, similiter \& eorum oratio, qui Domini cruciatus effictis atrocitatibus reddunt miserabiliores, praeterea \& tabulae statuaeve, ad speciem quam maxime miserabilem effictae, non ex historia evangelica, sed ex artificis imaginatione. Sic quidam pingunt Jesu matrem syncopi sub cruce collabentem exanimari, sed reclamante Chrysostomo. Eamdem pingunt septem perfossam gladiis. Ad hoc genus imagines suspirant \& illacrymant idiotae. Sed iidem yllacrimaturi sint, si spectent agi Euripidis Hecubam;' Erasmus, Opera Omnia IX (Lyon, 1706), p. 826. Erasmus here probably conflates Euripides' play with Hecuba's lament when Achilles kills her son Hector (Iliad, xxIv). Hecuba can be considered the 'paradigm of mourning motherhood'; Nicole Loraux, Mothers in Mourning (Ithaca: Cornell University Press, 1998), p. 40. 
It is in connection to, if not direct dependence on this reasoning that Jamete's Inquisitorial deposition seems to be aligned: Mary's swoon was inappropriate as it distracted from Christ's redemptive sacrifice. For Erasmus, ultimately, it was even pagan (Hecuba's grief for the death of her son Polydorus, for which she will take revenge, acts here as an obvious inversion of Mary's divine, compassionate, motherhood).

Given this particular background, Luis de Morales' Piedad can now be seen as a sophisticated exercise. ${ }^{72}$ It revisited and finally reformulated Sebastiano's 'Cobos Pietà' and it did so struggling to find a satisfactory solution in between two extremes. ${ }^{73}$ His Piedad fits on the one hand with a growing sensibility to Mary's dignity and decorum (as an increasing number of voices kept on claiming at the outset of the Counter Reformation). ${ }^{74}$ She 'stands' still (John 15:25-27), right at the foot of the cross, her stiff body replicating the verticality of the cross behind her. On the other hand, Christ is not just lying on her lap - the way traditional iconography showed her - but she is holding Him up. Her redemptory agency is made visually explicit, passively, in her grimacing face, but also actively in her body language. Summing up, the Virgin is at the same time overtaken with pain without having her faith stumble.

Morales' is a masterful response in the search for a visual language that paired decorum with emotion, empathy with respectful worship. It was this aesthetic and moral balance that made Luis de Morales' paintings very popular among Spanish ecclesiastics, such as San Juan de Ribera, the well-known Bishop of Counter-Reformation Valencia - who owned the Portacroce mentioned before - or the Bishop of Cordoba and Inquisitor, Diego de Simancas, who patronized some of his works as Bishop of Badajoz in the later years of his life. In finding this balance, the status of images as religious mediations themselves played a crucial role. I will now turn to this final aspect.

72 In Spanish the most proper term for this iconography in the sixteenth century encapsulates its theological meaning: Quinta Angustia (Mary' Fifth Sorrow).

73 Analogous experiments were developed in Flanders in the fifteenth century. Morales, however, turned as we have seen only to Italian sources. For the former, see Reindert L. Falkenburg, "The Decorum of Grief: Notes on the Representation of Mary at the Cross in Late Medieval Netherlandish Literature and Painting', in Icon to Cartoon: A Tribute to Sixten Ringbom, (ed.) M. Trettu Knapas and A. Ringbom (Helsinki: Taidehistorian Seura, 1995), pp. 65-89. 


\section{Reception: Images and Worship}

Out of the numerous ecclesiastical patrons for whom Luis de Morales worked in his lifetime only the last one, Diego de Simancas, is credited with having written extensively on religious images. In his Institutiones Catholicae (1552), written, as the title reads, 'for the extirpation of heresy', the Inquisitor and maybe even patron of Morales' Piedad put 'idolatry' and 'images' at the very top of his list of heterodox deviations from Catholic doctrine. ${ }^{75}$ The date $\left(155^{2}\right)$ is important as it predates by more than a decade the Council of Trent's pronouncement on the doctrine of religious images. Obviously, Spanish religious authorities were reacting in the context of the Counter Reformation, but also with their own religious and political agenda.

After asking for the highest form of adoration for religious images, the cult of latria, an extreme that would be hard to find in any coeval Italian source, Simancas quoted the Sixth General Council (680) for banning all 'indecent images, that move to lasciviousness or laughter more than piety together with those pictures that, in panels or any other [support] seek to deceive the eyes [oculorum praestigiatrices], to corrupt the minds, or incite to voluptuousness. So they should not be painted again. And whoever does it, should be excommunicated'. It is important to notice that Simancas' unequivocal support of image adoration and his fierce judgment on the 'deceptive' nature of art cannot be taken together as representing something like an 'Inquisitorial taste'. During his Roman trial, Archbishop Carranza - the most famous of Simancas' victims - quoted by heart exactly the same medieval Council against a witness that had seen him remove some religious paintings imported from Brussels from the altar. 'Painters do not paint as they used to anymore' counter-attacked Carranza in a tone of regret, as he recommended replacing some of the 'old ones' (imágenes de las antiguas). It seems that Inquisitor and accused came to coincide in their artistic conservatism. ${ }^{76}$

75 Diego de Simancas, Institutiones Catholicae (Valladolid: Egidio de Colomies, 1552). The hypothesis that Diego de Simancas might have been Morales' patron for the Piedad is developed by Bäcksbacka, Luis de Morales, pp. 113-27, and is followed in later literature (Rodríguez de Ceballos, 'El mundo espiritual', p. 199). It is not conclusive nor necessary for my argument. Diego de Simancas was Bishop of Badajoz (1569-79) but his relation to Luis de Morales needs to be completely revised. On Diego de Simancas, see now Kimberley Lynn, Between Court and Confessional: The Politics of Spanish Inquisitors (Cambridge: Cambridge University Press, 2013).

76 See the trial in José Ignacio Tellechea Idígoras, Fray Bartolome de Carranza, documentos históricos (Madrid: Real Academia de la Historia, 1962-81), ch. 5, pp. 95-96 and ch. 4, pp. $457-58$. 
However, against the backdrop of Simancas' defense of image adoration and confessional function we can at least guess why the work of Luis de Morales would have pleased the Inquisitor's criteria. Standing out against the deep black background, Morales' Pietà negates spatial depth, substituting the artifice of perspective with the real presence of Christ's body, marked with the signs of His Passion. If Sebastiano's solution had been to stress the painting's iconicity while blurring both emotional and physical exterior signs, Morales, on the contrary, chose to emphasize the historical or testimonial nature of painting. In exegetical terms Sebastiano gravitated towards a parabolical figura of Christ's sacrifice, while Morales turned to the historical witnessing of his suffering. However paradoxical, Morales' painting is the result of a process of pictorial experimentation that had begun half a century before, in Rome, with a formula created to address, and at the same time sidestep the threat of hypocrisy.

When three hundred years later Théophile Gautier still considered 'truth' the one fundamental rule distinctive to the Spanish School, consciously or unconsciously he also pointed out the complex historical ground in which Spanish realism seemed to be rooted. My claim is not that we should follow Gautier's 'inquisitorial' logic. I am not proposing to deconstruct this tradition by unmasking painters' and painting's shameful intentions, nor I am arguing that Spanish art of this period should be seen through the lens of Nicodemism. At the same time, however, the story told here shows that when considering the religious and political tensions that pervaded Spanish social life, by carefully listening to people's fears and anxieties we will better understand those - often not less careful - decisions artists were making. These had to do with doctrinal matters debated in this time of political reform, but also with a more dramatic break that raised, and immediately after questioned that images were the direct expression of people's beliefs. Artists were now forced to consider and then respond to this challenge. In the end, whether sixteenth-century Spaniards believed or not is a question better left in the hands of the Inquisitors. 